\title{
Skin healing and scale regeneration in fed and unfed sea bream, Sparus auratus
}

\author{
Florbela A Vieira ${ }^{1 *}$, Silvia F Gregório ${ }^{1}$, Serena Ferraresso ${ }^{2}$, Michael AS Thorne ${ }^{3}$, Rita Costa ${ }^{1}$, Massimo Milan$^{2}$, \\ Luca Bargelloni ${ }^{2}$, Melody S Clark ${ }^{3}$, Adelino VM Canario ${ }^{1}$ and Deborah M Power ${ }^{1}$
}

\begin{abstract}
Background: Fish scales are an important reservoir of calcium and phosphorus and together with the skin function as an integrated barrier against environmental changes and external aggressors. Histological studies have revealed that the skin and scales regenerate rapidly in fish when they are lost or damaged. In the present manuscript the histological and molecular changes underlying skin and scale regeneration in fed and fasted sea bream (Sparus auratus) were studied using a microarray 3 and 7 days after scale removal to provide a comprehensive molecular understanding of the early stages of these processes.

Results: Histological analysis of skin/scales revealed 3 days after scale removal re-epithelisation and formation of the scale pocket had occurred and 53 and 109 genes showed significant up or down-regulation, respectively. Genes significantly up-regulated were involved in cell cycle regulation, cell proliferation and adhesion, immune response and antioxidant activities. 7 days after scale removal a thin regenerated scale was visible and only minor changes in gene expression occurred. In animals that were fasted to deplete mineral availability the expression profiles centred on maintaining energy homeostasis. The utilisation of fasting as a treatment emphasised the competing whole animal physiological requirements with regard to barrier repair, infection control and energy homeostasis.

Conclusions: The identification of numerous genes involved in the mitotic checkpoint and cell proliferation indicate that the experimental procedure may be useful for understanding cell proliferation and control in vertebrates within the context of the whole animal physiology. In response to skin damage genes of immune surveillance were up-regulated along with others involved in tissue regeneration required to rapidly re-establish barrier function. Additionally, candidate fish genes were identified that may be involved in cytoskeletal remodelling, mineralization and stem cells, which are of potential use in aquaculture and fish husbandry, as they may impact on the ability of the fish to produce structural proteins, such as muscle, efficiently.
\end{abstract}

\section{Background}

In vertebrates the skin performs many functions, not least of which is protection from the external environment. It has a relatively well conserved organisation, composed of the epidermis, dermis, and hypodermis, but is obviously adapted to the habitat and environmental challenges that a particular species faces. In aquatic organisms, such as fish, the skin is also an important osmoregulatory organ and the scales act as a reservoir of minerals [1-5]. The living non keratinized epidermis

\footnotetext{
* Correspondence: fvieira@ualg.pt

${ }^{1}$ Comparative and Molecular Endocrinology Group, Centre for Marine Sciences (CCMAR), Universidade do Algarve, Campus de Gambelas, 8005-139 Faro, Portugal

Full list of author information is available at the end of the article
}

and scales are a functional specialisation of teleost skin and the latter structures are dermal skeletal elements which form after metamorphosis in juvenile fish [6]. The scales in most teleosts are classified as elasmoid and consist of an external calcified layer and a thicker, partially calcified basal plate composed of closely packed type I collagen fibrils $[7,8]$. The basal plate overlays elasmoblasts (scale forming cells) and resorption involves the action of osteoclasts (scale resorbing cells) [9-13].

Scale removal in fish involves the loss of epidermal cells, scales and the superficial dermis. Such skin wounds heal rapidly in fish and the skin surface is quickly covered by mucus and re-epithelization from the wound margin occurs within a few hours $[1,14]$. Moreover, within a few weeks a new scale with the size and
C Biomed Central

() 2011 Vieira et al; licensee BioMed Central Ltd. This is an Open Access article distributed under the terms of the Creative Commons Attribution License (http://creativecommons.org/licenses/by/2.0), which permits unrestricted use, distribution, and reproduction in any medium, provided the original work is properly cited. 
characteristics of a mature scale is completely re-grown $[8,15]$. This process of regeneration has been divided into four stages; starting with re-epithelization and the differentiation of scale-forming cells (day 1-2), followed by rapid production of external layer matrix (days 3-5), the production of basal-plate matrix (days 6-14) and finally partial mineralization of the basal plate (very intense by days 14-28) [8]. To date most studies on scale formation and/or regeneration have focussed on morphology $[7,16]$, with a limited understanding of the associated molecular basis, which is restricted to single gene studies. For example, co-expression of the estrogen receptor $2 \mathrm{a}($ esr $2 a)$, apolipoprotein $\mathrm{Eb}$ (apoeb) and sonic hedgehog (shh) has been linked to cell proliferation, differentiation and metabolic activity of the zebrafish epidermis in fin buds and growing scales [17-19]. The ectodysplasin-A-receptor (EDAR) has been shown to be required for scale initiation and may also be involved in the cross-talk between the epidermal basal cells and the differentiating scaleforming cells in medaka (Oryzias latipes) [20]. Moreover, recently MMP-2 and MMP-9 were shown to have a role in scale regeneration in zebrafish [21]. Removal of scales damages a key barrier of the innate immune system and consequently provokes an inflammatory response and activation of the processes associated with healing and skin and scale re-growth [22,23].

Along with their protective role, scales also provide a readily mobilized reservoir of calcium in periods of highcalcium demand and contribute to whole organism calcium homeostasis $[2,3,24,25]$. Calcium in its soluble form is essential for cellular enzyme activities, nerve and muscle function and is a significant component of skeletal architecture including bone and scales. Its levels are tightly regulated [26-28]. Calcium in bones and scales is closely associated with phosphorus in the form of hydroxyapatite. Hence regeneration and repair of scales not only affects calcium levels, but also those of phosphorus, which like calcium, is essential for bone integrity and has numerous other essential cellular functions [29].

The aim of this study is to gain an understanding of the molecular basis of scale regeneration in a teleost fish, the gilthead sea bream (Sparus auratus, Linnaeus 1758). In particular, calcium and phosphorus are essential for the calcified matrix of forming scales and the effect on regeneration of manipulating minerals via food availability was assessed. Scale regeneration was monitored by analysing temporal changes in skin/scale morphology and modifications in the transcriptome determined using a sea bream specific oligo microarray.

\section{Results and Discussion}

The experiments represented three treatments: animals with scales removed (WS), fasted animals (ST) and fasted animals with scales removed (STWS); and control animals $(\mathrm{N})$. The sea bream scale regeneration process was evaluated at two time points, day 3 and day 7 after scale removal. Food deprivation was employed as a treatment to reduce the transcriptome associated with cellular/tissue metabolism and modify whole animal mineral homeostasis and in this way cause a relative amplification in the gene expression signals generated as a result of the cellular response to scale removal. There were no evident signs of stress, no mortality occurred during the experimental trial and no overt infections were evident. Sea bream from which food was withheld failed to increase in length and weight during the experiment compared to those that were fed irrespective of the presence or absence of scales. The good condition of the animals was substantiated by measurements of plasma components. Lactate and glucose were the plasma components measured to investigate the condition of animals.

\section{Morphology of sea bream skin/scales}

Transverse sections of skin from all the experimental groups at both time points (days 3 and 7) of the experiment were analysed (Figure 1). Sea bream skin had the typical organisation of teleost skin and was composed of three well defined layers: the epidermis, dermis and hypodermis which overlaid a fat layer that varied in thickness. The scales were each enclosed within a scale pocket and were composed of a mineralized external layer and a partially mineralized basal plate. The scale pocket was localized in the superficial dermis and projected into and was covered by a thin layer of epidermis (Figure 1B, H and 1I). Removal of the scales damaged the epidermis, dermis and scale pocket, the latter two tissues became exposed to the ambient water and the epidermis which remained attached to the dermis hung loose (Figure 1A). The ontogeny of the regenerative response was similar in all sea bream. Histology of the day 3 samples revealed a rapid repair process, with the epidermis already re-established and the enclosed scale pocket without a scale was visible in the dermis (Figure $1 \mathrm{C}$ and $1 \mathrm{~F}$ ). Hence within 3 days, the animals had reestablished their external barrier and protection to the environment and 7 days after scale removal a thin regenerated scale was visible (Figure 1D, E and 1G). From a morphological perspective the regeneration process in sea bream was similar to that described in the cichlid Hemichromis bimaculatus [1,30] and also in zebrafish and goldfish $[8,18]$.

\section{Plasma analyses}

No significant difference in plasma glucose or plasma lactate (frequently used as indicators of physiological stress) was observed between any of the experimental groups analyzed on day 3 of the experiment (Table 1). 


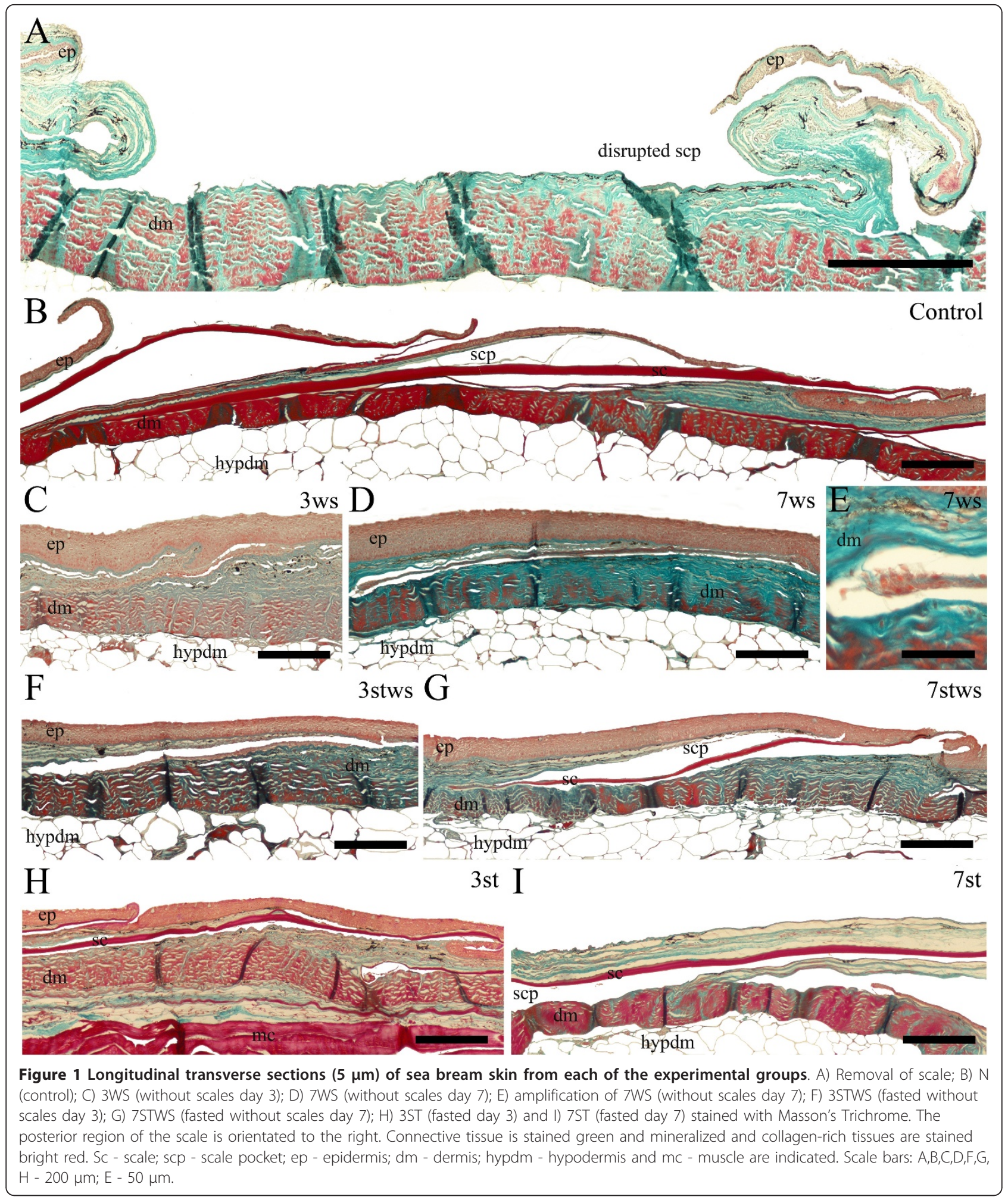

Plasma glucose and lactate levels were both within the normal range for fish with normal metabolism and not suffering from stress [31-33]. No significant difference in total plasma calcium was found between any of the experimental groups and the control (Table 1), with concentrations in the normal range for intact animals of this species [34]. Plasma phosphorus levels also varied within normal levels (Table 1). However, a significant ( $p$ 
Table 1 Sea bream plasma parameters concentrations measured for the different groups at day 3

\begin{tabular}{|c|c|c|c|c|}
\hline Group & Calcium $\left(\mathrm{mmol}^{-1}\right)$ & Phosphorus (mmol.L $\left.\mathrm{L}^{-1}\right)$ & Glucose $\left(\mathrm{mmol}^{-1} \mathrm{~L}^{-1}\right)$ & Lactate $\left(\mathrm{mmol}^{\left.-\mathrm{L}^{-1}\right)}\right.$ \\
\hline $3 \mathrm{~N}$ & $2.984 \pm 0.158$ & $3.256 \pm 0.077$ & $4.539 \pm 0.370$ & $2.562 \pm 0.343$ \\
\hline $3 W S$ & $3.377 \pm 0.116$ & $3.755 \pm 0.234$ & $4.542 \pm 0.573$ & $2.821 \pm 0.352$ \\
\hline 3ST & $3.047 \pm 0.113$ & $3.349 \pm 0.182$ & $5.631 \pm 0.628$ & $3.154 \pm 0.228$ \\
\hline 3STWS & $2.986 \pm 0.069$ & $2.685 \pm 0.225$ & $5.131 \pm 0.281$ & $2.779 \pm 0.379$ \\
\hline
\end{tabular}

Values correspond to mean values \pm SEM from each group (individual biological replicates of $n=8$ ).

$<0.05)$ reduction in plasma phosphorus was measured in animals without scales which were fasted $(2.685$ $\mathrm{mmol} / \mathrm{L} \pm 0.225)$ in relation to the fed animals without scales $(3.755 \mathrm{mmol} / \mathrm{L} \pm 0.234)$. Nutrient depletion will amplify the effects of scale removal as both will cause increased mineral requirements by the fish in order to maintain whole body calcium and phosphorus homeostasis. Phosphorus is mainly obtained via the diet, whilst calcium can be obtained from both the diet and seawater [35]. Hence when fish are deprived of food the requirement for these minerals will be evidenced first via the phosphorus measurements (as observed here) that probably acts as an indicator of enhanced calcium mobilization from sea water by the fish.

\section{Molecular analyses}

Although the sea bream oligo-array had been previously annotated [36], the sequences of the oligos used in the microarray were reanalysed in order to take advantage of the recent large increase in molecular data available for teleosts. Of the 39,379 oligo probes on the array, 16,025 (40.6\%) showed significant match similarity to a known protein in uniprot database $\left(1 \mathrm{e}^{-10}\right)$ [37]. To facilitate the understanding of the underlying cellular processes of epidermis and scale regeneration, a number of comparisons were carried out at days 3 and 7 after scale removal. Control animals $(\mathrm{N})$ were compared with fed animals without scales (WS), fasted animals (ST) and fasted animals without scales (STWS). To specifically dissect out the enhanced effects of scale removal under conditions of nutrient depletion, an additional comparison of fasted animals (ST) with fasted animals which had had scales removed (STWS) was made. Table 2 shows the numbers of differentially regulated genes under these comparisons, with the major effect shown for the fasted vs. fasted without scales analysis (additional file 1). It is clear that within the skin, the response to scale removal is rapid and of short duration (even under food deprivation). To obtain a clear overview of the transcripts with a conserved response between the different comparisons Venn diagrams were generated for the up-regulated genes at both day 3 and 7 (Figure 2). For example of the 53 up-regulated genes in fish without scales compared to the control, 27 were also significantly up-regulated in unfed fish without scales compared to control and fasted fish.

By day 7 there were much reduced levels of differential expression between groups with only 49 up-regulated probes compared to 729 up-regulated probes over the four comparisons at day 3. The considerable difference in gene expression found between day 3 and 7 reflects the rapid repair response and temporally different processes that accompany skin repair. Since most of the expression changes took place within three days and resulted in the differential expression of a considerable number of probes, an initial overview of the major processes involved was conducted before a more detailed gene-by-gene analysis.

\section{Overview of expression profiles via GO enrichment and Ingenuity pathway analysis}

Microarray probes were classified according to their Gene Ontology terms (GO ID) in order to determine whether particular biological processes were enriched in response to the different treatments. Overall, 25.3\% of the probes were associated with at least a GO term. The most represented Biological Processes on the microarray were "cellular processes" (GO:0009987) (24\%), "regulation of biological process" (GO:0050789) (16\%), "response to stimulus" (GO:0050896) (13\%) and "multicellular organismal development” (GO:0007275) (12\%) (Additional file 2). Interestingly, when GO enrichment analysis was performed on differentially expressed genes from different comparisons, no particular Biological

Table 2 Microarray results in terms of number of probes differentially expressed between the different experimental groups

\begin{tabular}{lcccc}
\hline & \multicolumn{3}{c}{ N compared with } & ST compared with STWS \\
\hline Day 3 & WS & ST & STWS & \\
Up-regulated & 53 & 181 & 66 & 429 \\
Down-regulated & 109 & 71 & 127 & 340 \\
Total & $\mathbf{1 6 2}$ & $\mathbf{2 5 2}$ & $\mathbf{1 9 3}$ & $\mathbf{7 6 9}$
\end{tabular}

Day 7

$\begin{array}{lllll}\text { Up-regulated } & 8 & 14 & 17 & 10\end{array}$

$\begin{array}{lllll}\text { Down-regulated } & 4 & 31 & 31 & 11\end{array}$

$\begin{array}{lllll}\text { Total } & 12 & 45 & 48 & 21\end{array}$




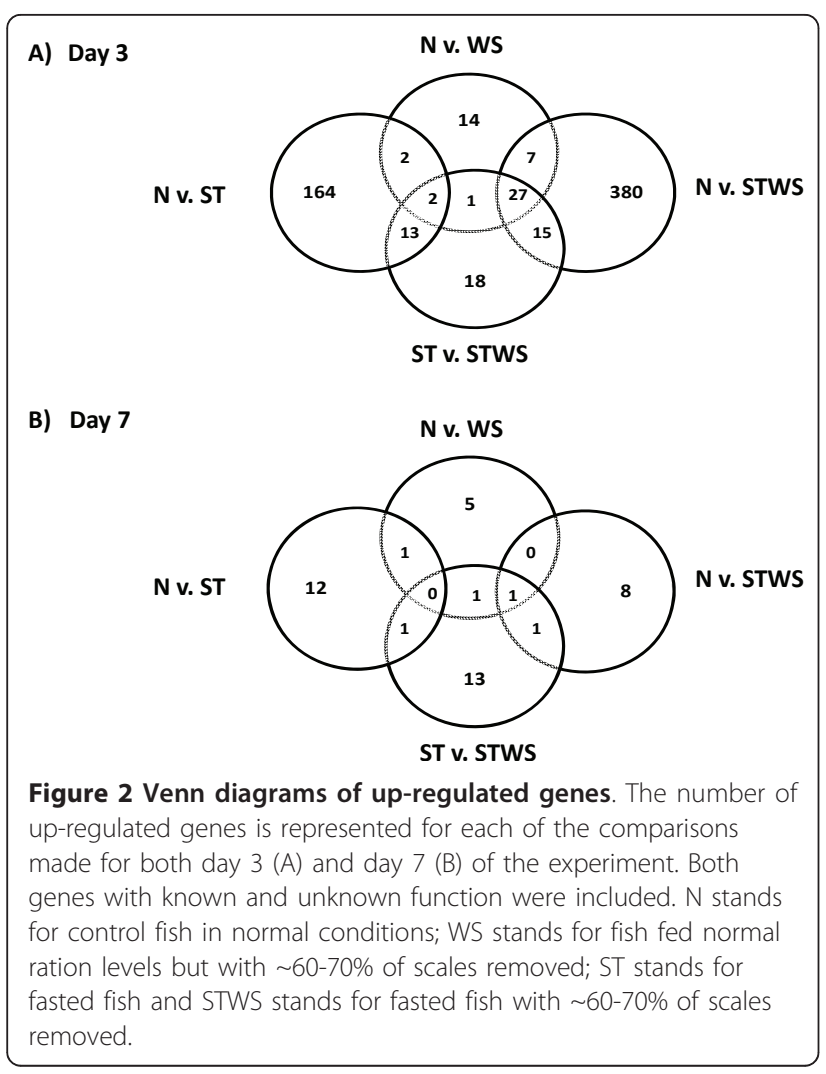

Process term was enriched amongst the up-regulated gene lists with the exception of "cellular processes" between the STWS and the ST groups. The down-regulated gene lists revealed a significant reduction in metabolic processes, indicating that the animals were repartitioning their translation machinery away from normal housekeeping functions towards repair and regeneration (data not shown). This conclusion is substantiated by the Ingenuity pathway analysis software (IPA) results which identified the main molecular and cellular biological functions that were significantly affected (Table 3) and also which physiological systems with regard to development and function were involved (Additional file 3). The IPA top networks for all the comparisons which included animals with scales removed produced matches to cancer, indicating that genes which have been implicated in non-controlled cell proliferation in human may be involved in normal cellular proliferation in fish skin. Not surprisingly the top networks also included those involved in the cell cycle, cellular growth and proliferation, and biological processes included tissue/organ development and morphology and haematopoiesis. Lipid metabolism was one of the most significant functions represented in IPA in the fasted fish indicating the effects of nutrient depletion on the general metabolism of the animals. This finding was substantiated in the STWS comparisons, which also included networks involved in vitamin and mineral metabolism (Table 3, Additional file 3). The Ingenuity results, whilst providing an overview of the main cellular processes affected in the experiments, provide more detail than the simplified GO enrichment analyses and link in far more directly to analysis of individual genes and their putative functional identification.

\section{Most highly up-regulated genes: individual analyses}

Analysis of the differentially expressed genes in each of the comparisons was restricted to up-regulated genes and those which could be assigned a putative function via the Uniprot/Swissprot and Uniprot/Trembl databases [37]. Nonetheless, one aspect to bear in mind is that approximately $50 \%$ of the oligoarray transcripts had no known match to any transcripts with functional annotation which limits the overall analysis and therefore the pathways invoked could only be inferred from those genes with a functional annotation. The unknowns will form an important aspect of future investigations, particularly those that are differentially expressed in more than one comparison (see Figure 2 and additional file 1). The following discussion focuses on the results of the samplings at 3 days.

\section{The effect of scale removal in fed animals}

This initial analysis compared the most differentially expressed probes in the group of animals which had scales removed with control animals (Table 4). These probes shared high sequence similarity with genes involved in cell cycle regulation, cell proliferation and adhesion, immune response and antioxidant activities. Whilst many of the putative functions have been ascribed from human or mammalian research, both the receptor-transporting protein 2 and IFI56 have been identified in salmon and carp, respectively as interferon responsive genes induced in response to viral infections $[38,39]$. In addition Galectin 3 and LOC406638 have putative roles in the immune response, whilst methionine sulfoxide reductase and cytochrome p $4502 \mathrm{~W} 1$ have antioxidant activities, indicating that removal of scales provoked an inflammatory response, with activation of cell defence mechanisms to protect the animal against the breach in external protection.

During regeneration, the immune system is important for immune surveillance and control of pathogens, but there is increasing awareness of the importance of immune physiology. The latter term refers to the role of the immune system in tissue homeostasis and it is increasingly recognised that complement, lymphocytes and monocyte derived cells (MDC) promote tissue growth and regeneration in mammals (reviewed by [40]). This aspect has received little attention in fish, as research about immune functioning is generally focussed 
Table 3 Top three network functions obtained by IPA for the differentially expressed genes of each comparison 3 days after scale removal.

\begin{tabular}{lc}
\hline Group Top Network Functions & $\begin{array}{c}\text { Score } \\
\text { Mocus } \\
\text { Control v. Without scales (WS) }\end{array}$ \\
\hline Small Molecule Biochemistry, Genetic Disorder, Metabolic Disease & 34 \\
Cell Morphology, Cancer, Cell Cycle & 17 \\
Cell-To-Cell Signaling and Interaction, Cellular Movement, Tissue Development & 15 \\
\hline Control v. Starved (ST) & 26 \\
\hline Lipid Metabolism, Nucleic Acid Metabolism, Small Molecule Biochemistry & 46 \\
Cellular Development, Cellular Growth and Proliferation, Connective Tissue Development and Function & 22 \\
Cell-To-Cell Signaling and Interaction, Hematological System Development and Function, Immune Cell Trafficking & 31 \\
\hline Control v. Starved without scales (STWS) & 16 \\
\hline Cancer, Gastrointestinal Disease, Tumor Morphology & 16 \\
Cancer, Reproductive System Disease, Genetic Disorder & 39 \\
Lipid Metabolism, Molecular Transport, Small Molecule Biochemistry & 20 \\
\hline Starved (ST) v. Starved without scales (STWS) & 30 \\
\hline Cancer, Gastrointestinal Disease, DNA Replication, Recombination, and Repair & 16 \\
Lipid Metabolism, Small Molecule Biochemistry, Vitamin and Mineral Metabolism & 14 \\
Endocrine System Development and Function, Lipid Metabolism, Skeletal and Muscular System Development and & 36 \\
Function & 23
\end{tabular}

Score and number of molecules in each network are given.

on infection or disease control, an important priority for aquaculture (see reviews by [41-43]). Immunological diseases and lymphoid tissue structure and development are an enriched category (IPA) for transcripts in fish with regenerating skin and scales. In addition to the probes listed in the tables for the different treatments, transcripts for chemokines (CCL3 and CCL4) associated with monocytes and macrophages were also identified and it remains to be established if their presence is associated with immune surveillance or immune physiology and tissue regeneration [44]. Recent investigations in stem cell biology have linked several molecules traditionally associated with the immune cells/function to stem cells. For example, immune associated transcripts differentially expressed in skin/scale from fasted fish 3 days after scale removal included CD55 (delay accelerating factor), a modulator of complement activity and a recently identified candidate surface marker for early and late definitive endoderm [45]. Similarly, CD200, a novel immunosuppressive molecule, has been identified as a biomarker of the hair follicle bulge in human and dog skin [46-48]. Future work will be required to establish the role of immune physiology and cellular defence mechanisms in the regenerating fish skin and also the involvement of stem cells in this process.

At the same time as the immune response, there is a clear requirement to rapidly re-construct this external barrier with various genes involved in metabolic processes such as amino acid biosynthesis and also cell division and proliferation. Interestingly, in a link with the IPA results, several of these genes have been described in cancer studies. Cyclin-dependant kinase inhibitor is involved in haematopoietic cell cycle regulation and has been shown to be over-expressed in breast and prostate cancer [49]; Sphase kinase-associated protein interacts with c-myc during the G1-S phase transition of the cell and is a co-factor of c-myc which is a known transcriptional regulator of oncoproteins and involved in cell growth, apoptosis and oncogenesis [50]; whilst the mitotic check point serine/ threonine protein kinase has been shown to be preferentially expressed in cells with a high mitotic index [51]. Adaptation to new conditions involves an element of cytoskeletal re-modelling [52], as evidenced by the up-regulation of cytokeratin which has been associated with epidermis development, fibrinolysis and also regulation of angiogenesis. It is tempting to speculate that the up-regulation of cytokeratin in response to scale removal may represent a keratinization-like phenotype provoked by the osmotic shock. There was also up-regulation of genes involved in apoptosis such as Galectin-3 and the multifunctional S-phase kinase-associated protein (described earlier) and the somewhat confusingly named cation transport regulator-like protein $[50,53]$. Hence competing interests between infection/inflammation control and cellular proliferation/tissue repair in fish with scales removed appear to be ongoing.

\section{The effect of food deprivation with no scale removal}

Skin tissue metabolism is clearly being redirected as the animals cope with adaptation to food deprivation. One 
Table 4 "Top 20 known genes" up-regulated in the group without scales (WS) in relation to the control (N) on day 3

\begin{tabular}{|c|c|c|c|c|c|}
\hline Clone & LogFold & $\begin{array}{l}\text { adj } \\
\text { P- } \\
\text { val }\end{array}$ & Acc. Number & Gene Identification & Putative function \\
\hline SAPD03340 & 2.794 & 0.021 & Q6P0E4 & $\begin{array}{c}\text { Type I cytokeratin, enveloping } \\
\text { layer }\end{array}$ & Structural protein. \\
\hline SAPD14269 & 2.453 & 0.001 & Q9BUX1 & $\begin{array}{c}\text { Cation transport regulator-like } \\
\text { protein } 1\end{array}$ & Potential component of the unfolded protein response. \\
\hline$\overline{\text { SAPD07472 }}$ & 2.389 & 0.022 & Q5QGT7 & $\begin{array}{c}\text { Receptor-transporting protein } \\
2\end{array}$ & $\begin{array}{l}\text { Promotes functional cell surface expression of olfactory receptors, but } \\
\text { also shown to be induced by interferon in response to infection. }\end{array}$ \\
\hline SAPD04707 & 2.227 & 0.004 & Q5QGT7 & $\begin{array}{c}\text { Receptor-transporting protein } \\
2\end{array}$ & $\begin{array}{l}\text { Promotes functional cell surface expression of olfactory receptors, but } \\
\text { also shown to be induced by interferon in response to infection. }\end{array}$ \\
\hline SAPD01524 & 2.217 & 0.021 & Q9BUX1 & $\begin{array}{c}\text { Cation transport regulator-like } \\
\text { protein } 1\end{array}$ & Potential component of the unfolded protein response. \\
\hline$\overline{\text { SAPD25017 }}$ & 2.008 & 0.000 & NP_999926 & $\begin{array}{l}\text { Hypothetical protein } \\
\text { LOC406638 }\end{array}$ & GTP binding, immune function, specifically related to bacteria. \\
\hline SAPD05261 & 1.934 & 0.016 & Q7T2R0 & IFI56 & Immune function: antiviral effect. \\
\hline SAPD23209 & 1.796 & 0.003 & 043175 & $\begin{array}{l}\text { D-3-phosphoglycerate } \\
\text { dehydrogenase }\end{array}$ & $\begin{array}{l}\text { Amino acid biosynthesis, cell growth and differentiation, metabolic } \\
\text { development and CNS function. }\end{array}$ \\
\hline SAPD24645 & 1.771 & 0.006 & P00480 & $\begin{array}{l}\text { OTCase Ornithine } \\
\text { transcarbamylase }\end{array}$ & Amino acid biosynthesis. \\
\hline SAPD22329 & 1.756 & 0.003 & Q8TAV3 & $\begin{array}{l}\text { Cytochrome P450 2W1 EC } \\
\text { 1.14.14.- CYPIIW1 }\end{array}$ & Oxidative degradation and detoxification. \\
\hline SAPD12115 & 1.752 & 0.024 & Q08380 & $\begin{array}{l}\text { Galectin-3-binding protein } \\
\text { precursor }\end{array}$ & Cell attachment and adhesion. May play a role in host defenses. \\
\hline SAPD22251 & 1.735 & 0.006 & Q6PGQ7 & $\begin{array}{l}\text { Protein aurora borealis } \\
\text { (HsBora) }\end{array}$ & Cell division and mitosis. \\
\hline SAPD15427 & 1.712 & 0.015 & NP_932346 & $\begin{array}{l}\text { Methionine sulfoxide } \\
\text { reductase B3 isoform } 1\end{array}$ & Antioxidant repair. \\
\hline SAPD22138 & 1.582 & 0.004 & Q16667 & $\begin{array}{l}\text { Cyclin-dependent kinase } \\
\text { inhibitor } 3\end{array}$ & Haematopoietic ell cycle regulation. \\
\hline SAPD25026 & 1.531 & 0.014 & NP_001003640 & $\begin{array}{l}\text { Hypothetical protein } \\
\text { LOC445246 }\end{array}$ & $\begin{array}{l}\text { RNA binding. Plectrin domain present in some forms of cytoskeletal } \\
\text { muscle and ribosomal S10 protein (translation). }\end{array}$ \\
\hline SAPD19262 & 1.418 & 0.008 & Q13309 & $\begin{array}{l}\text { S-phase kinase-associated } \\
\text { protein } 2\end{array}$ & $\begin{array}{l}\text { Cell cycle progression/cell growth and apoptosis. Ubiquitination and } \\
\text { degradation of proteins. }\end{array}$ \\
\hline SAPD19571 & 1.394 & 0.015 & O60566 & $\begin{array}{c}\text { Mitotic checkpoint serine/ } \\
\text { threonine-protein kinase BUB1 } \\
\text { beta }\end{array}$ & Mitotic checkpoint protein. \\
\hline SAPD17118 & 1.393 & 0.041 & Q9UBR1 & Beta-ureidopropionase (BUP-1) & Amino acid biosynthesis. \\
\hline SAPD13849 & 1.390 & 0.021 & Q9H7X7 & Rab-like protein 5 & $\begin{array}{c}\text { Regulator of haematopoietic cells with roles in cell growth, survival, } \\
\text { differentiation, cytokine production, chemotaxis, vesicle trafficking } \\
\text { and phagocytosis. }\end{array}$ \\
\hline SAPD21101 & 1.355 & 0.015 & P06493 & $\begin{array}{l}\text { Cyclin-dependent kinase } 1 \\
\text { (CDK1) }\end{array}$ & $\begin{array}{c}\begin{array}{c}\text { Key role in the cell cycle. Required for entry into } S \text { phase and } \\
\text { mitosis. }\end{array}\end{array}$ \\
\hline
\end{tabular}

The "Top 20 known genes" were taken from 36 transcripts of which 16 showed no match to genes of known function. Putative function was assigned via BLAST sequence similarity searching. All matches are in excess of $1.0 \mathrm{e}^{-10}$. Definitions: LogFold = Estimate of the log2-fold change corresponding to the effect; adj $\mathrm{p}$ val $=$ adjusted as described in methods.

aspect of this is a reduction in cell division with the upregulation of angiopoietin-related protein 4 (ANGPTL4), MYND and KIAA0711, all of which have been shown to play roles in the inhibition of proliferation (Table 5) [54-56]. Another regulator of a proto-oncogene (MYC) is present in the form of ubiquitin carboxyl-terminal hydrolase and levels of MYC decline is response to intracellular stress signals [57]. Molecular signals of cell stress are also present with up-regulation of antioxidants
(glutathione-S-transferase, methionine-R-sulphoxide reductase, alcohol dehydrogenase and cytochrome p450 2W1).

During periods of food deprivation fish seem to maintain energy homeostasis, at least during the initial stages of fasting, by mobilizing energy reserves such as lipids and hepatic glycogen and reduction in the rate of glucose utilization and enhancement of lipid metabolism [31,58-60]. In fact, the genes differentially expressed in 
Table 5 "Top 20 known genes" up-regulated in the fasted group (ST) in relation to the control (N) on day 3

\begin{tabular}{|c|c|c|c|c|c|}
\hline Clone & LogFold & $\begin{array}{l}\text { adj } \\
\text { P- } \\
\text { val }\end{array}$ & Acc. Number & Gene Identification & Putative function \\
\hline SAPD06994 & 4.485 & 0.017 & NP_001073454 & Cardiomyopathy associated 5 & $\begin{array}{l}\text { Maintenance of structural integrity of muscle cells, involved in } \\
\text { muscle biology and pathology. }\end{array}$ \\
\hline SAPD01696 & 4.201 & 0.000 & Q6B4J3 & Alcohol dehydrogenase Class VI & Oxidoreductase, but also developmental regulation in medaka. \\
\hline SAPD22431 & 3.956 & 0.006 & IPI00015568 & $\begin{array}{l}\text { Homolog of Homo sapiens Protein } \\
\text { KIAA0711 }\end{array}$ & Transcriptional repression. \\
\hline SAPD06947 & 3.919 & 0.038 & NP_001019764 & $\begin{array}{l}\text { Zinc finger, MYND domain } \\
\text { containing } 17\end{array}$ & Functions as a co-repressor. Control of proliferation. \\
\hline SAPD25996 & 3.677 & 0.001 & Q9BY76 & $\begin{array}{l}\text { Angiopoietin-related protein } 4 \\
\text { precursor }\end{array}$ & $\begin{array}{l}\text { Inhibition of proliferation, migration and tubule formation of } \\
\text { endothelial cells. May exert a protective action on endothelial } \\
\text { cells via endocrine action. }\end{array}$ \\
\hline $\begin{array}{l}\text { SAPD07090 } \\
\end{array}$ & 3.525 & 0.013 & Q96RU2 & $\begin{array}{l}\text { Ubiquitin carboxyl-terminal } \\
\text { hydrolase } 28\end{array}$ & $\begin{array}{l}\text { DNA damage response check point. Regulates myc which is } \\
\text { involved in cell proliferation, growth and apoptosis. }\end{array}$ \\
\hline SAPD09760 & 3.499 & 0.001 & IPI00298828 & Beta-2-glycoprotein I precursor & Blood coagulation and immune response. \\
\hline SAPD06461 & 3.484 & 0.001 & Q9BY76 & $\begin{array}{l}\text { Angiopoietin-related protein } 4 \\
\text { precursor }\end{array}$ & $\begin{array}{l}\text { Inhibition of proliferation, migration and tubule formation of } \\
\text { endothelial cells. May exert a protective action on endothelial } \\
\text { cells via endocrine action. }\end{array}$ \\
\hline SAPD20351 & 3.415 & 0.000 & IPI00298828 & Beta-2-glycoprotein I precursor & Blood coagulation and immune response. \\
\hline SAPD20440 & 3.230 & 0.000 & NP_065109 & $\begin{array}{l}\text { Patatin-like phospholipase domain } \\
\text { containing } 2\end{array}$ & $\begin{array}{c}\text { Energy homeostasis. May play a role in response of organism } \\
\text { to starvation, enhancing hydrolysis of triglycerides etc to be } \\
\text { used in situations of energy depletion. }\end{array}$ \\
\hline SAPD25836 & 3.176 & 0.001 & Q9Y3D2 & Methionine-R-sulfoxide reductase B2 & Antioxidant repair. \\
\hline SAPD14080 & 2.926 & 0.003 & O75385 & $\begin{array}{l}\text { Serine/threonine-protein kinase } \\
\text { ULK1 }\end{array}$ & $\begin{array}{l}\text { Involved in autophagy, induced by nutrient depletion to } \\
\text { provide amino acids within cells. }\end{array}$ \\
\hline SAPD02047 & 2.925 & 0.008 & Q90278 & $\begin{array}{l}\text { Homolog of Carassius auratus } \\
\text { Kainate receptor beta subunit. }\end{array}$ & Synaptic plasticity. \\
\hline SAPD22329 & 2.511 & 0.000 & Q8TAV3 & $\begin{array}{l}\text { Cytochrome P450 2W1 EC 1.14.14.- } \\
\text { CYPIIW1 }\end{array}$ & Oxidative degradation and detoxification. \\
\hline SAPD10144 & 2.426 & 0.003 & Q15119 & $\begin{array}{l}2 \text { Pyruvate dehydrogenase kinase } \\
\text { isoform } 2\end{array}$ & Regulation of glucose metabolism. \\
\hline SAPD23550 & 2.415 & 0.016 & Q99972 & $\begin{array}{l}\text { Myocilin precursor Trabecular } \\
\text { meshwork-induced glucocorticoid } \\
\text { response protein }\end{array}$ & $\begin{array}{c}\text { Obstruction of fluid outflow from trabecular network in the eye, } \\
\text { but functions in other tissues unknown. Glucocorticoid } \\
\text { response protein. }\end{array}$ \\
\hline SAPD08799 & 2.392 & 0.002 & IPI00328648 & $\begin{array}{l}\text { Homolog of Homo sapiens CD151 } \\
\text { antigen }\end{array}$ & $\begin{array}{l}\text { Involved in cellular processes including cell adhesion and } \\
\text { migration. }\end{array}$ \\
\hline SAPD08134 & 2.331 & 0.004 & P28906 & $\begin{array}{l}\text { Hematopoietic progenitor cell } \\
\text { antigen CD34 precursor }\end{array}$ & Cell-cell or cell-matrix adhesion. Role in early haematopoiesis. \\
\hline SAPD06600 & 2.263 & 0.013 & NP_060650 & $\begin{array}{l}\text { DEAD/H Asp-Glu-Ala-Asp/His box } \\
\text { polypeptide } 32\end{array}$ & RNA metabolism, gene regulation. \\
\hline SAPD01688 & 2.233 & 0.023 & Q6PH41 & Glutathione S-transferase, theta 3 & Antioxidant, stress protein. \\
\hline
\end{tabular}

The "Top 20 known genes" were taken from 45 transcripts of which 25 showed no match to genes of known function. Putative function was assigned via BLAST sequence similarity searches. All matches are in excess of $1.0 \mathrm{e}^{-10}$. Table definitions are the same as for Table 4 .

the array from the groups in which food was withheld suggests that lipid metabolism and angiogenesis are the main processes induced in the treated fish. Pyruvate dehydrogenase is involved in production of energy via glucose metabolism and ANGPTL4, in addition to a role in non-proliferation, and has also been shown to be a regulator of glucose homeostasis, lipid metabolism and angiogenesis $[61,62]$, but this more conventional pathway may be supplemented by the actions of serine/ threonine kinase ULK1 and a patatin-like gene. The former has been shown to be involved in autophagy induced by nutrient depletion to provide essential amino acids within cells, whilst the latter may enhance hydrolysis of triglycerides to provide free fatty acids to other tissues to be oxidised in situations of energy depletion $[63,64]$. Taken together the results appear to indicate that fish under food deprivation "slow down" their metabolism to save energy and break down macromolecules to release energy.

Interestingly, two of the genes putatively identified here play roles in human diseases, which may be of relevance to the condition of the fish in this experiment. 
Myospryn has been shown to be up-regulated in hypertrophy inducing conditions in humans and is involved in maintaining muscle integrity [65] and the phenotype of mutants of the CD151 antigen include fragility of the skin and mucus membranes [66]. Starvation directly affects muscle wastage in mammals and fish $[67,68]$. Hence these genes may be playing a similar structural role in fish as they do in humans, and represent novel candidates for understanding this physiological response in fish.

\section{The combined effect of food deprivation and scale removal}

The most differentially regulated genes in this group of animals display a gene expression profile, which is intermediate between the previous two (Table 6 and Figure 2) with representatives of cell proliferation and cell cycle control genes, energy homeostasis, antioxidant repair enzymes and the immune response. The results of the gene expression profiles in this group clearly represent the whole organism trade-offs that are occurring within the fish for several competing essential cellular processes. Food deprivation leads to a reduction in metabolism, but if the animal is challenged, then there is the question of what predominates in terms of the minimal requirements for survival. Trade-offs occur [69] and a recent study in salmon clearly documents the competing transcriptomic responses to food deprivation and immune challenge [70]. Which requirements predominate in this study is difficult to determine and entail further studies. Perhaps, not surprisingly, there is an indication that repair processes are slowed under food deprivation with the enhanced presence of genes involved in blood coagulation and wound healing (Beta-2-glycoprotein I and lymphatic vessel endothelial hyaluronic acid receptor). To verify this hypothesis, further experimentation will be required with a more detailed sampling regime over the same or a slightly elongated time course with the same treatments.

Curiously, one of the genes up-regulated in this group of animals, cytosolic sulfotransferase 2, which is involved in detoxification reactions, and participates in the activation and deactivation of hormones, neurotransmitters, steroids and bile acids [71], has been correlated with low plasma P levels in trout [72]. The preceding study developed several intestinal mRNA biomarkers for $\mathrm{P}$ depletion in the rainbow trout although only sulfotransferase 2 was modified in the present study presumably because the target tissue was different. The results of the present study in the sea bream suggest that cytosolic sulfotransferase 2 may be a promising general marker of $P$ depletion in fish and certainly merits further investigation.

\section{The effect of scale removal under food deprivation compared with food deprivation}

There was not such a pronounced effect as had been expected with scale removal and food deprivation and so an additional comparison was carried out between fasted animals and fasted animals with scales removed. Indeed, this comparison did produce the highest number of differentially expressed genes (429 up-regulated probes, compared with 53 (WS), 181 (ST) and 66 (STWS) when the latter three treatments were compared with control animals. Surprisingly little overlap in significantly up-regulated transcripts or modified networks were found between animals without scales and fasted animals without scales (see Tables, 3, 4, 7 and Figure 2A). The reason for this lack of overlap is difficult to explain but may result from asynchronous regeneration associated with the slow-down in cellular metabolism and activation of alternative pathways to ensure barrier function when food is in short supply. This comparison provides the clearest signal of the sea bream response to scale removal with half of the 20 most up-regulated annotated probes involved in cell division and mitosis (Table 7). These probes are ideal candidates for the monitoring of cell division processes related to the regeneration of scales. Of the remaining annotations, there are representatives of cell growth and metabolism (Interleukin enhancer binding factor, phosphoserine aminotransferase, D-3-phosphoglycerate dehydrogenase), cell proliferation (Macrophage stimulating 1 hepatocyte growth factor-like), and cell signaling (Inositol monophosphatase). The function of the multifunctional ubiquitin in the present experiments remains to be elucidated as this gene has a large number of roles [73] including cell cycle regulation, DNA repair, embryogenesis, regulation of transcription and apoptosis. Interestingly, this comparative analysis may reveal the first hint of the start of mineralization processes. In particular mutations in the gene 3-beta-hydroxysteroiddelta8, delta7-isomerase which catalyses the conversion of delta(8)-sterols to their corresponding delta (7) isomers is linked to chondrodysplasia punctata in humans (Conradi-Hunermann-Happle syndrome) that causes punctiform calcification of cartilage [74]. It remains to be established if this gene also influences the calcification process in fish but if it does it may represent a useful biomarker. Moreover, it suggests that up-regulation of transcripts involved in calcification occurs early in regeneration well before the most active phase of this process (estimated at 14-28 days in goldfish) [8].

The overexpression of developmental genes is already known to be involved in stem cell activation and in epidermal-dermal interactions. Examples such as FGFs, Wnts and SHH were not observed to be differentially regulated in the experiments described here, which 
Table 6 "Top 20 known genes" up-regulated in the group fasted without scales (STWS) in relation to the control (N) on day 3

\begin{tabular}{|c|c|c|c|c|c|}
\hline Clone & LogFold & $\begin{array}{l}\text { adj } \\
\text { P- } \\
\text { val }\end{array}$ & $\begin{array}{l}\text { Accession } \\
\text { Number }\end{array}$ & Gene Identification & Putative function \\
\hline SAPD06461 & 3.396 & 0.002 & Q9BY76 & $\begin{array}{l}\text { Angiopoietin-related protein } 4 \\
\text { precursor }\end{array}$ & $\begin{array}{l}\text { Inhibition of proliferation, migration and tubule formation of } \\
\text { endothelial cells. May exert a protective action on endothelial } \\
\text { cells via endocrine action. }\end{array}$ \\
\hline SAPD22431 & 3.138 & 0.031 & IPI00015568 & $\begin{array}{l}\text { Homolog of Homo sapiens Protein } \\
\text { KIAA0711 }\end{array}$ & Transcriptional repression. \\
\hline SAPD09760 & 2.742 & 0.007 & IPI00298828 & $\begin{array}{l}\text { Homolog of Homo sapiens Beta-2- } \\
\text { glycoprotein I precursor }\end{array}$ & Blood coagulation and immune response. \\
\hline SAPD03340 & 2.530 & 0.039 & Q6P0E4 & Type I cytokeratin, enveloping layer & Structural protein. \\
\hline SAPD20440 & 2.519 & 0.001 & NP_065109 & $\begin{array}{l}\text { Patatin-like phospholipase domain } \\
\text { containing } 2\end{array}$ & $\begin{array}{c}\text { Energy homeostasis. May play a role in response of organism to } \\
\text { starvation, enhancing hydrolysis of triglycerides etc to be used } \\
\text { in situations of energy depletion. }\end{array}$ \\
\hline SAPD22329 & 2.469 & 0.000 & Q8TAV3 & Cytochrome P450 2W1 (CYPIIW1) & Oxidative degradation and detoxification. \\
\hline SAPD02465 & 2.422 & 0.016 & Q6P2U4 & $\begin{array}{c}\text { Homolog of Brachydanio rerio } \\
\text { Sulfotransferase family, cytosolic } \\
\text { sulfotransferase } 2\end{array}$ & $\begin{array}{c}\text { Metabolic action. Increases water solubility of compounds plus } \\
\text { bioactivation of metabolites. }\end{array}$ \\
\hline SAPD20351 & 2.364 & 0.006 & IPI00298828 & $\begin{array}{l}\text { Homolog of Homo sapiens Beta-2- } \\
\text { glycoprotein I precursor }\end{array}$ & Blood coagulation and immune response. \\
\hline SAPD25836 & 2.176 & 0.017 & Q9Y3D2 & Methionine-R-sulfoxide reductase B2 & Antioxidant repair. \\
\hline SAPD24645 & 1.841 & 0.004 & P00480 & $\begin{array}{l}\text { Ornithine carbamoyltransferase, } \\
\text { mitochondrial precursor }\end{array}$ & Amino acid biosynthesis. \\
\hline SAPD10144 & 1.793 & 0.033 & Q15119 & $\begin{array}{l}\text { Pyruvate dehydrogenase kinase } \\
\text { isoform } 2\end{array}$ & Regulation of glucose metabolism. \\
\hline SAPD23209 & 1.724 & 0.004 & 043175 & $\begin{array}{l}\text { D-3-phosphoglycerate } \\
\text { dehydrogenase (3-PGDH) }\end{array}$ & $\begin{array}{l}\text { Amino acid biosynthesis, cell growth and differentiation, } \\
\text { metabolic development and CNS function. }\end{array}$ \\
\hline SAPD22251 & 1.705 & 0.013 & Q6PGQ7 & Protein aurora borealis HsBora & Cell division and mitosis. \\
\hline SAPD23370 & 1.704 & 0.012 & Q9Y5Y7 & $\begin{array}{l}\text { Lymphatic vessel endothelial } \\
\text { hyaluronic acid receptor } 1 \text { precursor }\end{array}$ & Facilitates cell migration during wound healing and inflamation. \\
\hline SAPD14269 & 1.702 & 0.017 & Q9BUX1 & $\begin{array}{c}\text { Cation transport regulator-like } \\
\text { protein } 1\end{array}$ & Potential component of the unfolded protein response. \\
\hline SAPD25026 & 1.689 & 0.007 & NP_001003640 & Hypothetical protein LOC445246 & $\begin{array}{l}\text { RNA binding. Plectrin domain present in some forms } \\
\text { ofcytoskeletal muscle and ribosomal S10 protein (translation). }\end{array}$ \\
\hline SAPD13849 & 1.589 & 0.005 & Q9H7X7 & Rab-like protein 5 & $\begin{array}{c}\text { Regulator of haematopoietic cells with roles in cell growth, } \\
\text { survival, differentiation, cytokine production, chemotaxis, vesicle } \\
\text { trafficking and phagocytosis. }\end{array}$ \\
\hline SAPD16979 & 1.496 & 0.003 & NP_998427 & $\begin{array}{l}\text { Eukaryotic translation initiation } \\
\text { factor } 5 \mathrm{~A}\end{array}$ & Translation. \\
\hline$\overline{\text { SAPD19571 }}$ & 1.384 & 0.016 & O60566 & $\begin{array}{l}\text { Mitotic checkpoint serine/ } \\
\text { threonine-protein kinase BUB1 beta }\end{array}$ & Control of the cell cycle. \\
\hline$\overline{\text { SAPD21410 }}$ & 1.342 & 0.025 & Q8WWL7 & G2/mitotic-specific cyclin-B3 & Control of the cell cycle. \\
\hline
\end{tabular}

The "Top 20 known genes" were taken from 37 transcripts of which 17 showed no match to genes of known function. Putative functionality was assigned via BLAST sequence similarity searching. All matches are in excess of $1.0 \mathrm{e}^{-10}$. Table definitions are the same as for Table 4 .

could be for several reasons, including 1) some of those genes were not represented in the oligo array e. g. sonic hedgehog $(\mathrm{SHH})$ and 2 ) the timescale of the experiment was not ideal to identify changes in gene expression of developmental genes associated with skin healing since by day 3 histological analysis revealed that epidermis is already re-established. Furthermore, metalloproteinases 2 (MMP-2) and 9 (MMP-9) have been recently suggested to have a role in scale regeneration in zebrafish [21]. However, MMP-2 is not represented in the sea bream microarray and although MMP-9 is represented (SAPD23115) it did not change significantly between the groups analyzed. Of the metalloproteinases present on the microarray (MMP-9, MMP-7.MMP-15 and MMP-28) only matrilysin (MMP-7) was modified and it was down-regulated in unfed fish without scales compared to the unfed fish on day 3 of the experiment. The sea bream oligo-array results were also queried for known calcitropic factors, for example, PTH (parathyroid hormone) and PTH 
Table 7 "Top 20 Known genes" up-regulated in the group fasted without scales (STWS) in relation to fasted group (ST) on day 3

\begin{tabular}{|c|c|c|c|c|c|}
\hline Clone & LogFold & $\begin{array}{l}\text { adj } \\
\text { P- } \\
\text { val }\end{array}$ & $\begin{array}{c}\text { Acc. } \\
\text { Number }\end{array}$ & Gene Identification & Putative function \\
\hline$\overline{\text { SAPD11916 }}$ & 4.104 & 0.009 & IPI00005781 & $\begin{array}{l}\text { Splice Isoform A of } \\
\text { Arachidonate 15- } \\
\text { lipoxygenase, type } \|\end{array}$ & Mediates allergic response. Restricts cell cycle progression. \\
\hline SAPD06895 & 3.415 & 0.002 & Q9Y617 & $\begin{array}{l}\text { Phosphoserine } \\
\text { aminotransferase }\end{array}$ & Amino acid biosynthesis. \\
\hline SAPD18045 & 3.355 & 0.000 & Q02241 & Kinesin-like protein KIF23 & Mitosis and cell cycle. \\
\hline SAPD00860 & 3.308 & 0.000 & P14635 & G2/mitotic-specific cyclin-B1 & Control of the cell cycle at G2/M transition. \\
\hline SAPD03340 & 3.298 & 0.006 & Q6P0E4 & $\begin{array}{l}\text { Type I cytokeratin, } \\
\text { enveloping layer }\end{array}$ & Structural protein. \\
\hline SAPD11351 & 3.260 & 0.003 & Q07426 & $\begin{array}{l}\text { Homolog of Carassius } \\
\text { auratus Keratin }\end{array}$ & Structural protein. \\
\hline SAPD04986 & 3.251 & 0.000 & IPI00027157 & $\begin{array}{l}\text { Homolog of Homo sapiens } \\
\text { CENP-F kinetochore protein }\end{array}$ & Involved in the cell cycle. \\
\hline SAPD17903 & 3.160 & 0.000 & IPI00412862 & $\begin{array}{l}\text { Homolog of Homo sapiens } \\
\text { M-phase phosphoprotein } 1\end{array}$ & Involved in the cell cycle. \\
\hline SAPD25367 & 3.039 & 0.001 & Q5XFY1 & $\begin{array}{l}\text { Macrophage stimulating } 1 \\
\text { Hepatocyte growth factor- } \\
\text { like }\end{array}$ & $\begin{array}{c}\text { Involved in cell proliferation and differentiation and tissue repair. } \\
\text { Epidermal wound healing. }\end{array}$ \\
\hline SAPD17933 & 3.017 & 0.000 & Q15125 & $\begin{array}{l}\text { 3-beta-hydroxysteroid-Delta8, } \\
\text { Delta7-isomerase }\end{array}$ & Involved in sterol contribution to bone development. \\
\hline SAPD23466 & 3.013 & 0.014 & XP_641063.1 & $\begin{array}{l}\text { Hypothetical protein } \\
\text { DDBDRAFT_0206057 }\end{array}$ & $\begin{array}{l}\text { Ubiquitin: multifunctional protein involved in cell cycle regulation, DNA } \\
\text { repair, protein degradation, regulation of transcription, apoptosis and } \\
\text { immune response. }\end{array}$ \\
\hline SAPD20573 & 2.987 & 0.000 & Q96EA4 & $\begin{array}{l}\text { Coiled-coil domain- } \\
\text { containing protein } 99\end{array}$ & $\begin{array}{l}\text { Involved in cell divsion via localisation of dyein and dynactin to } \\
\text { kinetochore. }\end{array}$ \\
\hline SAPD14492 & 2.975 & 0.001 & P33981 & $\begin{array}{l}\text { Dual specificity protein } \\
\text { kinase TTK }\end{array}$ & $\begin{array}{l}\text { Associated with cell proliferation. Essential for the alignment of } \\
\text { chromosomes by enhancing AURKB activity at centromere for mitotic } \\
\text { check point. }\end{array}$ \\
\hline SAPD09826 & 2.967 & 0.000 & Q5T113 & $\begin{array}{l}\text { Uncharacterized protein } \\
\text { C9orf156 Nef-associated } \\
\text { protein } 1\end{array}$ & $\begin{array}{l}\text { Hydrolyses acyl Co-A thioesters in vitro. Physiological function is } \\
\text { unknown. }\end{array}$ \\
\hline SAPD18060 & 2.898 & 0.001 & NP_060445 & Zwilch & $\begin{array}{l}\text { Essential component of the mitotic check point. Required for dyein- } \\
\text { dynactin and MAD1/MAD2 complexes onto kinetochores. }\end{array}$ \\
\hline SAPD22251 & 2.847 & 0.000 & Q6PGQ7 & $\begin{array}{l}\text { Protein aurora borealis } \\
\text { HsBora }\end{array}$ & Cell division and mitosis. \\
\hline SAPD11258 & 2.840 & 0.000 & P29218 & Inositol monophosphatase & Cell signalling. \\
\hline SAPD18820 & 2.778 & 0.003 & Q12905 & $\begin{array}{l}\text { Interleukin enhancer-binding } \\
\text { factor } 2\end{array}$ & $\begin{array}{l}\text { May regulate transcription of IL2 during T-cell activation: immune } \\
\text { response. Functions as a ds RNA binding protein to promote } \\
\text { autoimmunity. }\end{array}$ \\
\hline SAPD23209 & 2.755 & 0.000 & O43175 & $\begin{array}{l}\text { D-3-phosphoglycerate } \\
\text { dehydrogenase 3-PGDH }\end{array}$ & $\begin{array}{l}\text { Amino acid biosynthesis, cell growth and differentiation, metabolic } \\
\text { development and CNS function. }\end{array}$ \\
\hline SAPD18364 & 2.749 & 0.000 & Q1LV50 & $\begin{array}{c}\text { Centromere protein P CENP- } \\
\text { P }\end{array}$ & $\begin{array}{c}\text { Component of the centromeric complex, involved in mitotic progression } \\
\text { and chromosome segregation. }\end{array}$ \\
\hline
\end{tabular}

The "Top 20 known genes" were taken from 27 transcripts of which 7 showed no match to genes of known function. Putative functionality was assigned via BLAST sequence similarity searching. All matches are in excess of $1.0 \mathrm{e}^{-10}$. Table definitions are the same as for Table 4.

related peptide (PTHrP), which are related with calcium and phosphorus homeostasis in fish [35,75], and calcitonin, whose hypo or hypercalcemic role in fish is not yet clarified [11,76,77], no significant differences in expression were observed. The same was observed for other calcitropic hormones represented in the array (such as prolactin, prolactin-receptor and $\mathrm{PTH}$ receptor 1), but to a certain extent this was to be expected given the previously estimated timescales for these processes, albeit in a different species [8]. Moreover, the target tissue in the present study, the skin, is not recognised as an important source of these hormones which tend to be produced in appreciable levels by specific endocrine tissues. 


\section{Day 7 sampling}

The biggest changes in the skin/scale transcriptome amongst the treated groups occurred at day 3. By day 7 , when re-epithelisation had occurred and a thin regenerated scale was visible (Figure 1), relatively few differences were found when expression analyses were carried out. Over the four comparisons, a total of 49 probes were up-regulated only 21 of which had associated annotation, representing 17 putative unique transcripts (Table 8). It was also difficult to make generalisations about the on-going cellular processes, but the differentially expressed genes indicate a continued requirement for cell division and proliferation. The putative identification of the transforming acidic coiled coil 3 (TACC3) indicates the continuance of scale cell proliferation, as this gene in humans was shown to be involved in the control of cell growth and differentiation $[78,79]$. As in day 3, some genes are up-regulated in more than one of the comparisons made (Figure 2B). The GINS complex subunit 1 (PSF1 homolog) reported to be involved in regulating proliferation of stem cells, for example in response to acute bone marrow regeneration in mammals [80], is up-regulated in 3 of the four comparisons performed for both days 3 and 7 after scale removal where the factor analysed is the skin/scale regeneration. Taken together, the up-regulation of the GINS complex transcripts in all the groups where scales were removed at both day 3 and 7 of regeneration may indicate that, in teleosts, this transcript and its protein product may be regulating the process of skin/scale regeneration by the induction of cell proliferation.

There is also an element of cytoskeletal remodelling via the up-regulation of structural proteins (e.g. cytokeratin) and protein degradation. Similarly, as was noted with the fasted group (when compared with controls), there are a couple of genes up-regulated in sea bream, that in humans produce structural problems when defective. Mutations in Dynamin 2 produce abnormally large nuclei in skeletal muscle cells, resulting in muscle weakness [81], whilst serpin H1 is an essential chaperone in collagen synthesis, with deficiencies in humans resulting in the premature rupture of placental membranes [82]. As with the 3 days fasted vs. fasted without scales comparisons, at day 7 there are up-regulated transcripts potentially linked with mineralization. Such as, caldecrin precursor that exerts a hypocalcaemic activity, decreasing serum calcium, and may indicate that the fish is now actively mobilising calcium for scale mineralization.

\section{Real time RT-PCR}

To corroborate the microarray data gene-specific qPCRs were performed. In general, the direction of change in expression was concordant between qPCR and the microarray probes and a positive Pearson correlation was obtained between qPCR and probe_1 $\left(\mathrm{r}^{2}=0.895, \mathrm{p}\right.$ $<0.0001 \mathrm{n}=40)$ and between qPCR and probe_2 $\left(\mathrm{r}^{2}=\right.$ 0.901, $\mathrm{p}<0.0001 \mathrm{n}=40$ ) (Table 9). Despite the good correlation observed between the gene expression analyzed by qPCR and the microarray data, a few exceptions were observed, the qPCR fold-change for SPP1 transcript in group 3ST; for ColVA2 transcript in group 3WS; for Col1A1 transcript for group 3ST and for p22phox transcript in group 3STWS vs. starved group was not correlated with the microarray fold-change. The latter is explained by the high variability found for this gene in different individuals in the experimental groups. The best concordance between qPCR and microarray data is achieved when the observed microarray fold change is between 2 and 7 [36], and in the present experiments the genes analyzed by qPCR which had fold changes closest to the lower limit had lower correlations with the microarray data.

\section{Conclusions}

Fish skin is a very metabolically active organ which has crucial physiological functions, in osmotic regulation and is also an important immune barrier. Loss of scales and superficial wounds occur in both wild and captive teleosts and the vital importance of integument integrity means damage must be repaired as soon as possible. Although several studies exist which characterise tissue and cellular changes underlying skin regeneration in teleosts, molecular studies have largely been centred on scale formation and calcification, with the latter process not taking place until 14-28 days after scale removal [8]. The study described here, concentrates on the initial stages of scale removal and re-epithelialization. Our results show that this is a dramatic process, mainly occurring within the first three days after scale loss. The identification of numerous genes involved in the mitotic checkpoint and cell proliferation indicates that, with a more detailed time course experiment, this procedure represents a good model for understanding cell proliferation and control within the constraints of whole animal physiology. The utilisation of starvation as a treatment emphasised not only the essential processes underlying repair of the epithelia, but also the competing whole animal physiological requirements with regard to barrier repair, infection control and energy homeostasis. Comparison with human disease genes has identified several putative candidates in fish for the maintenance of cytoskeletal structure, which are of potential use in aquaculture and fish husbandry studies.

\section{Methods}

\section{Fish}

Juvenile sea bream (Sparus auratus) were maintained at the Centre of Marine Science (CCMAR) field station 
Table 8 Known Genes up-regulated in the 7 day sampling

\begin{tabular}{|c|c|c|c|c|c|}
\hline Clone & LogFold & $\begin{array}{c}\text { adj } \\
\text { P-val }\end{array}$ & Acc. Number & Gene Identification & Putative function \\
\hline \multicolumn{6}{|c|}{ Group without scales (WS) in relation to the control (N) } \\
\hline SAPD11984 & 5.158 & 0.002 & Q6E5T5 & Claudin 1 & Calcium-independent cell-adhesion activity. \\
\hline SAPD02183 & 3.186 & 0.015 & IPI00028413 & $\begin{array}{l}\text { Inter-alpha globulin } \\
\text { Inhibitor H3 }\end{array}$ & Hyaluronan metabolic processes. \\
\hline SAPD18084 & 2.505 & 0.012 & NP_001012506 & $\begin{array}{l}\text { Hypothetical protein } \\
\text { LOC503524 }\end{array}$ & $\begin{array}{l}\text { Oxidoreductase. Potential role in ketone utilisation as a secondary energy } \\
\text { source or generate precursors for lipid and sterol synthesis. }\end{array}$ \\
\hline SAPD01661 & 2.356 & 0.019 & Q5PSM1 & $\begin{array}{l}\text { Betaine homocysteine } \\
\text { methyltransferase }\end{array}$ & $\begin{array}{l}\text { Involved in methionine and betaine production (membrane composition, } \\
\text { osmolyte concentrations and protein unfolding). }\end{array}$ \\
\hline SAPD00429 & 1.129 & 0.013 & Q14691 & $\begin{array}{c}\text { DNA replication } \\
\text { complex GINS protein } \\
\text { PSF1 }\end{array}$ & Essential role in DNA replication. \\
\hline SAPD11480 & 1.049 & 0.032 & NP_001011729 & $\begin{array}{l}\text { Transforming acidic } \\
\text { coiled coil } 3\end{array}$ & Involved in centrosome/mitotic spindle dynamics, gene regulation. \\
\hline \multicolumn{6}{|c|}{ Group starved (ST) in relation to the control (N) } \\
\hline SAPD06461 & 3.250 & 0.003 & Q9BY76 & $\begin{array}{l}\text { Angiopoietin-related } \\
\text { protein } 4 \text { precursor }\end{array}$ & $\begin{array}{l}\text { Inhibition of proliferation, migration and tubule formation of endothelial } \\
\text { cells. May exert a protective action on endothelial cells via endocrine action. }\end{array}$ \\
\hline SAPD25996 & 2.942 & 0.011 & Q9BY76 & $\begin{array}{l}\text { Angiopoietin-related } \\
\text { protein } 4 \text { precursor }\end{array}$ & $\begin{array}{l}\text { Inhibition of proliferation, migration and tubule formation of endothelial } \\
\text { cells. May exert a protective action on endothelial cells via endocrine action. }\end{array}$ \\
\hline SAPD10144 & 1.903 & 0.023 & Q15119 & $\begin{array}{c}\text { Pyruvate } \\
\text { dehydrogenase kinase } \\
\text { isoform } 2\end{array}$ & Regulation of glucose metabolism. \\
\hline SAPD22443 & 1.672 & 0.008 & Q96DE5 & $\begin{array}{l}\text { Uncharacterized protein } \\
\text { C10orf104 }\end{array}$ & Cell cycle control. \\
\hline SAPD13172 & 1.576 & 0.014 & NP_001018326 & villin 2 ezrin like & Involved the cytoskeleton, may influence rho signalling pathways. \\
\hline \multicolumn{6}{|c|}{ Group starved and without scales (7STWS) in relation to the control (7N) } \\
\hline SAPD06461 & 2.772 & 0.011 & Q9BY76 & $\begin{array}{l}\text { Angiopoietin-related } \\
\text { protein } 4 \text { precursor }\end{array}$ & $\begin{array}{l}\text { Inhibition of proliferation, migration and tubule formation of endothelial } \\
\text { cells. May exert a protective action on endothelial cells via endocrine action. }\end{array}$ \\
\hline SAPD13675 & 2.203 & 0.029 & P40313 & $\begin{array}{l}\text { Chymotrypsin-like } \\
\text { protease CTRL-1 } \\
\text { precursor }\end{array}$ & $\begin{array}{c}\text { Protein degradation, degradation of old proteins for nutrition, control of } \\
\text { protein activity, defense activity. }\end{array}$ \\
\hline SAPD18879 & 1.437 & 0.007 & P50570 & Dynamin-2 & Involved in the cytoskeleton and muscle structure. \\
\hline SAPD00429 & 1.411 & 0.002 & Q14691 & $\begin{array}{c}\text { DNA replication } \\
\text { complex GINS protein } \\
\text { PSF1 } \\
\end{array}$ & Essential role in DNA replication. \\
\hline \multicolumn{6}{|c|}{ Group starved and without scales (7STWS) in relation to starved group (7ST) } \\
\hline SAPD03340 & 3.815 & 0.002 & Q6P0E4 & $\begin{array}{l}\text { Type I cytokeratin, } \\
\text { enveloping layer }\end{array}$ & Structural protein. \\
\hline SAPD01645 & 3.471 & 0.028 & Q99895 & $\begin{array}{l}\text { Caldecrin precursor } \\
\text { (Chymotrypsin C) }\end{array}$ & Protease activity and hypocalcaemic activity: decreases serum calcium. \\
\hline SAPD03019 & 1.759 & 0.044 & P35222 & $\begin{array}{l}\text { Catenin beta-1 Beta- } \\
\text { catenin }\end{array}$ & $\begin{array}{l}\text { Regulation of cell adhesion. Transcriptional co-activator via the Wnt } \\
\text { pathway (development, cell proliferation and differentiation). }\end{array}$ \\
\hline SAPD00618 & 1.469 & 0.007 & NP_998168 & $\begin{array}{l}\text { Hypothetical protein } \\
\text { LOC406276 }\end{array}$ & Important role in the modification and proliferation of neurons. \\
\hline SAPD00429 & 1.199 & 0.009 & Q14691 & $\begin{array}{c}\text { DNA replication } \\
\text { complex GINS protein } \\
\text { PSF1 } \\
\end{array}$ & Essential role in DNA replication. \\
\hline APD21979 & 1.121 & 0.037 & P50454 & Serpin $\mathrm{H} 1$ precursor & Essential in collagen synthesis. \\
\hline
\end{tabular}

The genes from the comparisons WS v. N, ST v. N, STWS v. N and STWS v. ST were taken from 8, 14, 17 and 10 transcripts of which 2, 9, 13 and 4, respectively, showed no match to genes of known function. Putative functionality was assigned via BLAST sequence similarity searching. All matches are in excess of $1.0 \mathrm{e}^{-10}$. Table definitions are the same as for Table 4. 
Table 9 Comparison of Fold-change values from qPCR target genes and microarray in the 3 day sampling

\begin{tabular}{|c|c|c|c|c|c|c|c|c|c|c|c|c|c|}
\hline \multirow[b]{2}{*}{ SAPD ID } & \multirow[b]{2}{*}{ Target Transcript } & \multicolumn{3}{|c|}{ WS } & \multicolumn{3}{|c|}{ ST } & \multicolumn{3}{|c|}{ STWS } & \multicolumn{3}{|c|}{ ST vs STWS } \\
\hline & & qPCR & $\begin{array}{c}\text { Probe } \\
1\end{array}$ & $\begin{array}{c}\text { Probe } \\
2\end{array}$ & qPCR & $\begin{array}{c}\text { Probe } \\
1\end{array}$ & $\begin{array}{c}\text { Probe } \\
2 \\
\end{array}$ & qPCR & $\begin{array}{c}\text { Probe } \\
1 \\
\end{array}$ & $\begin{array}{l}\text { Probe } \\
2\end{array}$ & qPCR & $\begin{array}{c}\text { Probe } \\
1\end{array}$ & $\begin{array}{c}\text { Probe } \\
2\end{array}$ \\
\hline SAPD03530 & Collagen $V$ alpha2 & $1.087^{*}$ & 0.780 & 0.758 & 0.836 & 0.814 & 0.782 & 0.646 & 0.598 & 0.580 & 0.772 & 0.734 & 0.741 \\
\hline SAPD01318 & Collagen I alpha1 & 0.838 & 0.398 & 0.547 & $1.294^{*}$ & 0.570 & 0.770 & 0.467 & 0.281 & 0.413 & 0.361 & 0.492 & 0.536 \\
\hline SAPD26722 & SPP1 & 0.552 & 0.116 & 0.130 & $1.109^{*}$ & 0.415 & 0.477 & 0.501 & 0.293 & 0.323 & 0.451 & 0.708 & 0.678 \\
\hline SAPD00344 & p22phox protein & 0.574 & 0.255 & 0.250 & 0.367 & 0.296 & 0.303 & 0.380 & 0.231 & 0.231 & $1.035^{*}$ & 0.780 & 0.763 \\
\hline SAPD13946 & Retinol-binding protein I & 3.097 & 1.738 & 2.117 & 0.877 & 0.680 & 0.765 & 1.840 & 2.023 & 2.329 & 2.098 & 2.976 & 3.044 \\
\hline SAPD02730 & $\begin{array}{l}\text { Glutathione S-transferase } \\
\text { A5 }\end{array}$ & 1.846 & 1.774 & 1.726 & 0.697 & 0.873 & 0.900 & 2.168 & 2.080 & 1.896 & 3.112 & 2.384 & 2.017 \\
\hline SAPD23304 & Cytochrome c & 1.373 & 1.874 & 1.949 & 0.625 & 0.873 & 0.845 & 2.149 & 2.180 & 2.278 & 3.438 & 2.498 & 2.696 \\
\hline SAPD20351 & Beta-2-glycoprotein I & 4.507 & 2.292 & 2.698 & 6.490 & 9.503 & 10.862 & 3.492 & 3.870 & 4.304 & 0.538 & 0.407 & 0.396 \\
\hline SAPD05261 & $\mathrm{IFI} 56$ & 2.144 & 3.291 & 3.213 & 0.372 & 0.422 & 0.417 & 1.385 & 2.193 & 1.906 & 3.728 & 5.202 & 4.574 \\
\hline SAPD02155 & pCNA & 1.329 & 1.754 & 1.62 & 0.558 & 0.517 & 0.489 & 1.598 & 1.692 & 1.585 & 2.862 & 3.273 & 3.240 \\
\hline
\end{tabular}

Comparisons were made for each treatment in relation to the control with the additional comparison of fasted vs. fasted without scales (ST vs. STWS). Values correspond to the Fold-change which was calculated by the ratio of mean expression values between treatment and control groups (individual biological replicates of $n=5$ for both $\mathrm{qPCR}$ and microarray). * indicate where differences between $\mathrm{qPCR}$ and microarray data were observed.

(Ramalhete, Faro, Portugal) in through-flow seawater tanks $(2000 \mathrm{~L})$ at $17-21^{\circ} \mathrm{C}, 36 \%$ salinity and $12 \mathrm{~h}$ light and $12 \mathrm{~h}$ dark photoperiod for several weeks prior to the start of the experiments. The maintenance of fish and subsequent experiments complied with the Guidelines of the European Union Council (86/609/EU) and was covered by a group 1 licence (Direcção-Geral de Veterinária, Portugal). Behaviour and health of animals was monitored visually each day and no mortality occurred during the experiment.

\section{Experimental Design}

Sea bream ( $\mathrm{n}=8$ fish/tank, $93.4 \pm 3.1 \mathrm{~g})$ were acclimatised for one week to the experimental circuit which consisted of 8 through-flow seawater tanks (500L), with water maintained at $19-21^{\circ} \mathrm{C}, 36 \%$ salinity and a $12 \mathrm{~h}$ light and $12 \mathrm{~h}$ dark photoperiod. Food was withheld from the fasted experimental groups for 1 week $(-7$ days) prior to removal of the scales which was considered day 0 of the trial (Figure 3). The experiment had 3 treatment groups: $\mathrm{ST}=$ fasted for duration of experiment; WS = scales removed at time 0 ; STWS $=$ fasted for duration of the experiment with scales removed at time 0 and the control group $(\mathrm{N})$ with no treatment but subjected to the same anaesthesia/handling as the treatments groups.

Duplicate tanks for each treatment were prepared (day 3 and day 7) and 8 fish were sampled from one tank 3 days after the scales had been removed and from the second tank 7 days after the scales had been removed. Two tanks contained the control fish and were sampled at the same time as the experimental groups at day 3 and 7 . To remove the scales, fish were lightly anaesthetised in 2-phenoxyethanol (1:5000, Sigma-Aldrich,
Madrid, Spain) and scales were removed (approximately 60-70\%) by wiping fish with a wet paper towel in order to minimize damage. For sampling fish were anaesthetised in 2-phenoxyethanol, as described above, weight and length was measured, blood collected and centrifuged (10,000 rpm for 5 minutes) and the plasma stored at $-20^{\circ} \mathrm{C}$. Fish were sacrificed by sectioning the spinal cord and skin was collected (approximately $1 \mathrm{~cm}^{2}$ ) from below the dorsal fin and carefully dissected free of muscle and snap frozen in liquid nitrogen and stored at $-80^{\circ}$

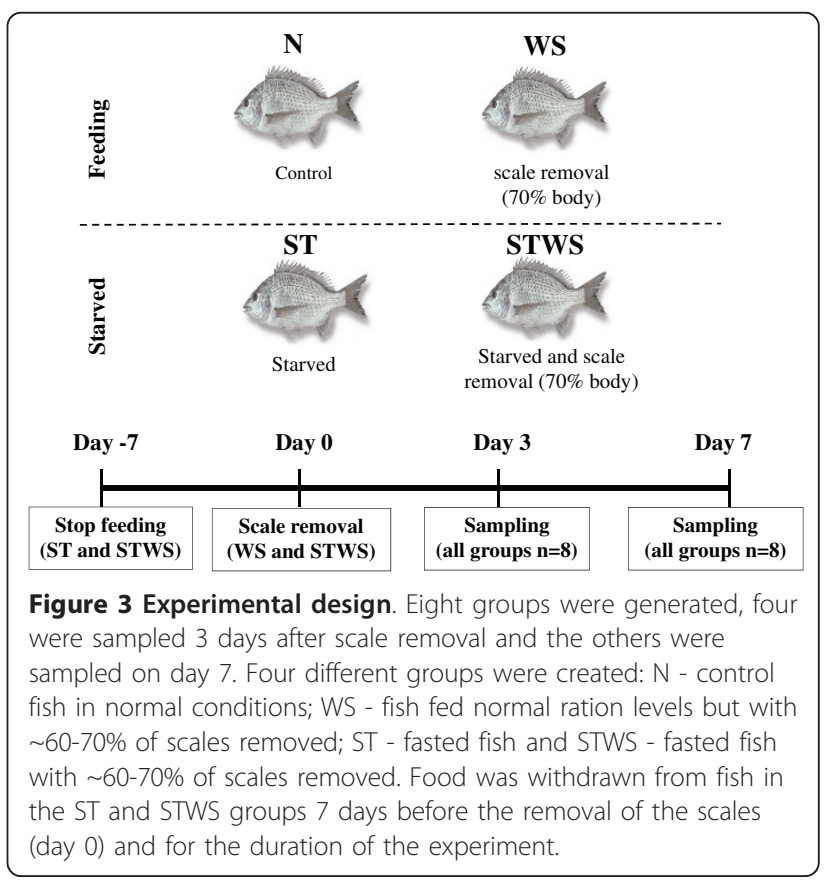


C. For histology, skin with some adhering muscle was fixed overnight at $4^{\circ} \mathrm{C}$ in $4 \%$ PFA.

\section{Plasma measurements}

To determine the possible effect of treatments on plasma composition but also to evaluate the physiological condition of the experimental and control animals, calcium, phosphorus, glucose and lactate were determined. Duplicate samples of sea bream plasma $(10 \mu \mathrm{l}$ diluted $1 / 4$ in milliQ water), collected from 8 fish/ experimental group, 3 days after the removal of scales were measured. Colourimetric tests were performed according to the manufacturers' instructions and absorbance measured with a microplate reader:

- Calcium: Calcium-o-C v/v kit (o-cresolphtalein, v/ v, colorimetric; Spinreact ref. 1001061, Spain), absorbance at $570 \mathrm{~nm}$.

- Phosphorus: Phosphorus - UV kit (Phosphomolybdate, uv; Spinreact ref. 1001155, Spain), absorbance at $340 \mathrm{~nm}$.

- Glucose: Glucose-TR kit (GOD-POD; Spinreact ref. 1001190/1001191/1001192, Spain), absorbance at $505 \mathrm{~nm}$.

- Lactate: Lactate kit (LO-POD Enzymatic colorimetric; Spinreact ref. 1001330, Spain), absorbance at $505 \mathrm{~nm}$.

\section{Histology of sea bream skin and scales}

To characterize sea bream skin and scale morphology, samples fixed in 4\% PFA were decalcified overnight in 0.5 M EDTA, pH 8, dehydrated through a graded ethanol series, saturated in xylene and impregnated and embedded in paraffin wax (Merck, Germany). Serial sections $(5 \mu \mathrm{m})$ of skin were mounted on 3-aminopropyltriethoxysilane (APES; Sigma-Aldrich, Madrid, Spain) coated glass slides. The sections were dried overnight at $37^{\circ} \mathrm{C}$, cooled to room temperature and stored or stained. To distinguish between collagen rich and/or mineralized and non-mineralized tissue, sections were stained with Masson's trichrome [83]. Skin sections were rapidly dehydrated through a graded series of alcohols, cleared in xylene and mounted in DPX mountant (BioChemika, Sigma-Aldrich, Madrid, Spain). Stained sections were analyzed using a microscope (Leica DM2000) coupled to a digital camera (Leica DFC480) and linked to a computer for digital image analysis.

\section{Sea bream microarray}

A $4 \times 44 \mathrm{k}$ oligo-array developed and validated for the gilthead sea bream by Ferraresso et al. [36] was used in this study. The array contained 39,379 sea bream oligonucleotide probes covering 19,715 unique transcripts and of these, 19,650 were represented by two non-overlapping probes and 65 were present as a single probe. Owing to the expansion of teleost sequences in the public databases since the publication of Ferraresso et al. [36], a re-annotation of probes was carried out with Blastx similarity searches against the Uniprot/Swissprot and Uniprot/Trembl databases [37]. Annotation was assigned for probes with an expected score in excess of $1 \mathrm{e}^{-10}$.

Total RNA was extracted from five individual fish using an RNeasy Mini kit (Qiagen, Hilden, Germany) according to the manufacturer's instructions. RNA quality and integrity were checked using an Agilent 2100 Bioanalyser (Agilent technologies, Palo Alto, CA) and only samples with an RNA integrity index number (RIN) $>7.5$ were processed for use in microarray analysis. Samples from each treatment group (5 replicates) were labelled with Cy3-dCTP and hybridizations were performed using the Agilent One-Colour MicroarrayBased Gene Expression Analysis protocol with the modifications described by Ferraresso et al. [36]. The arrays were scanned on an Agilent G2565BA DNA microarray scanner, at a resolution of $5 \mu \mathrm{m}$, and at two different sensitivity levels (XDR Hi $100 \%$ and XDR Lo $10 \%)$. The XDR Hi and XDR Lo images generated per array were analysed together and the data extracted. Background subtraction was performed using the standard procedure in the Agilent Feature Extraction Software 9.5.1. Spike-In Viral RNAs were used to control array hybridization intensities and ensure normalization gave a uniform signal across all microarray slides. The $\mathrm{R}$ [84] limma package [85] was used for microarray analysis. A factorial design of the treatments were compared by fitting a linear model [86] with differentially expressed clones selected by a Benjamini and Hochberg [87] globally adjusted p-value of 0.05 and a minimum two-fold change. The transcripts represented by two non-overlapping probes were only selected when both probes were differentially expressed.

The data discussed in this publication have been deposited in NCBI's Gene Expression Omnibus [88] and are accessible through GEO Series accession number GSE30717 (http://www.ncbi.nlm.nih.gov/geo/query/acc. cgi?acc=GSE30717).

\section{Gene Ontology Annotations and GO enrichment}

Accession numbers associated with the probe annotations were used to assign GO and GOSLIM terms [89]. $\mathrm{GO}$ enrichment was determined by a proportion test between the number of clones representing a GO term on the array compared to the number of differentially expressed clones representing the same GO term in a given comparison with a p-value cut-off of 0.05 . 


\section{Ingenuity pathway Analysis}

Cellular networks arising from the gene expression data were identified and established through the use of IPA (Ingenuity Systems, http://www.ingenuity.com). The sequences of differentially expressed genes from treatments collected at 3 days were all submitted to BLASTN in order to identify human orthologues. The accession numbers were extracted and used as identifiers in IPA together with the fold-changes of the corresponding differentially expressed genes. The Ingenuity knowledge base was used as a reference and direct and indirect relationships were included and no filters were applied. Bio functions, namely molecular and cellular functions and physiological system development and function significantly $(\mathrm{p}<0.05)$ related with the input dataset were identified. Networks were then algorithmically generated based on their connectivity and a score was assigned. The score was used to rank networks according to how relevant they were to the genes in the input dataset.

\section{Microarray validation by real time RT-PCR}

Array results were corroborated by real-time RT-PCR using when possible RNA extracted from the same individuals used for array analysis from all the different treatments at the 3 day time point. Ten genes were analysed and primers were designed using Beacon Design software (Premier Biosoft Int., Palo Alto, CA) (Table
10). For cDNA synthesis, $1 \mu \mathrm{g}$ of total RNA was pretreated with DNA-free Kit (Ambion, UK) to remove genomic DNA and then cDNA synthesis carried out using $250 \mathrm{ng}$ of DNAse-treated total RNA, $200 \mathrm{ng}$ of random hexamers (GE Healthcare, Little Chalfont, UK), $40 \mathrm{U}$ of MMLV reverse transcriptase (RT) (Promega, Southampton, UK) and 5 U of RNAguard Rnase inhibitor (GE Healthcare, Little Chalfont, UK) in a final reaction volume of $20 \mu \mathrm{l}$. Q-PCR was performed in duplicate reactions using SYBRgreen chemistry (Power SYBR $^{\circledR}$ Green PCR Master Mix, Applied Biosystems, UK) and the relative standard curve method, using a StepOnePlus qPCR thermocycler and StepOne software v2.0 (Applied Biosystems, UK). PCR cycling conditions were $10 \mathrm{~min}$ at $95^{\circ} \mathrm{C}$, followed by 55 cycles of $10 \mathrm{sec}$ at $95^{\circ} \mathrm{C}, 20 \mathrm{sec}$ at the optimal temperature for each primer pair (Table 10), and 30 seconds at $72^{\circ} \mathrm{C}$. A final melting curve was carried out between 60 and $95^{\circ} \mathrm{C}$ for all genes and each produced single products/dissociation curves. Standard curves relating initial template quantity to amplification cycle were generated using serial dilutions of linearized plasmid DNA containing the gene of interest or of RT-PCR specific product obtained from the same specie and tissue, and the efficiency of $\mathrm{qPCR}$ reactions ranged between $82-100 \%$, with the exception of SAPD20351 and SAPD13946 that had efficiencies of 73.1 and $78.6 \%$, respectively, and all gave $R^{2}>0.985$. All amplicons were sequenced to confirm specificity of the

Table 10 List of primers used for real time RT-PCR

\begin{tabular}{|c|c|c|c|c|c|c|}
\hline SAPD ID & Gene Name & $\begin{array}{l}\text { Accession } \\
\text { Number }\end{array}$ & Primer sequence $\left(5^{\prime} \rightarrow 3^{\prime}\right)$ & $\begin{array}{l}\text { Amplicon } \\
\text { (bp) }\end{array}$ & $\begin{array}{c}\text { Temp } \\
\left({ }^{\circ} \mathrm{C}\right)\end{array}$ & Efficiency \\
\hline SAPD20351 & $\begin{array}{l}\text { Beta-2-glycoprotein I } \\
\text { precursor }\end{array}$ & IPI00298828 & $\begin{array}{l}\text { F: TGGTTCGCCTCCTGTCTCC R: } \\
\text { GGTTCTGGTGACTCATCCTCTG }\end{array}$ & 178 & 60 & $73.1 \%$ \\
\hline SAPD01318 & $\begin{array}{l}\text { Collagen alpha1 I chain } \\
\text { precursor }\end{array}$ & P02452 & $\begin{array}{l}\text { F: AGACCTGCGTATCCCCAACTC R: } \\
\text { GCCACCGTTCATAGCCTCTCC }\end{array}$ & 110 & 57 & $83.4 \%$ \\
\hline SAPD03530 & $\begin{array}{c}\text { Collagen alpha2 } V \text { chain } \\
\text { precursor }\end{array}$ & IPI00293881 & $\begin{array}{c}\text { F: ACCTGTGACGACCTGAAGAGATGC R: } \\
\text { TGGATGGGTTGGCGGAGATGC }\end{array}$ & 145 & 60 & $86.8 \%$ \\
\hline SAPD23304 & Cytochrome c & P81459 & $\begin{aligned} & \text { F: } \text { AGGCATTCGTCCAGAAGTGTG R: } \\
& \text { TGGCATCGGTGTAGGAGTAGC }\end{aligned}$ & 132 & 56 & $84 \%$ \\
\hline SAPD05261 & IFI56 & Q7T2R0 & $\begin{array}{l}\text { F: ACCTCGCTGCTCAGTACCTC R: } \\
\text { GCCTCCTCCGCCAAATCAATG }\end{array}$ & 184 & 57 & $87.7 \%$ \\
\hline SAPD02730 & Glutathione S-transferase A5 & Q7RTV2 & $\begin{array}{c}\text { F: AGACGTGCTGCTGCTTGAATGC R: } \\
\text { TGGCTTCGGCTTCCTCTTGCTG }\end{array}$ & 157 & 60 & $99.1 \%$ \\
\hline SAPD00344 & P22phox protein & NP_001027717 & $\begin{array}{l}\text { F: ATGCTTGCCACCGTCCTG R: } \\
\text { TCTTGATGCTCTCTGCGACTG }\end{array}$ & 139 & 60 & $82.4 \%$ \\
\hline SAPD02155 & $\begin{array}{l}\text { Proliferating cell nuclear } \\
\text { antigen (pCNA) }\end{array}$ & P12004 & $\begin{array}{l}\text { F: GAGCAGCTGGGTATTCCAGA R: } \\
\text { CTGTGGCGGAGAACTTGACT }\end{array}$ & 148 & 60 & $83.4 \%$ \\
\hline SAPD13946 & $\begin{array}{l}\text { Retinol-binding protein I, } \\
\text { cellular }\end{array}$ & P82980 & $\begin{array}{l}\text { F: TCCGCACCATAACCACCTTCAAG R: } \\
\text { CCAGCCTCGTCCTTCCTTCTCC }\end{array}$ & 168 & 60 & $78.6 \%$ \\
\hline SAPD26722 & SPP1 protein & NP_001002308 & $\begin{array}{c}\text { F: AGGTTGCTGACAGTTCTGAGAG R: } \\
\text { GCGGCTGCTGCTACAATG }\end{array}$ & 130 & 57 & $92.2 \%$ \\
\hline- & Ribosomal protein S18 & AM490061 & $\begin{array}{l}\text { F: AGGGTGTTGGCAGACGTTAC R: } \\
\text { CTICTGCCTGTTGAGGAACC }\end{array}$ & 164 & 60 & $92.1 \%$ \\
\hline
\end{tabular}


PCR reaction. Ribosomal protein S18 (S18) expression was quantified using the same conditions as the other genes. No statistically significant differences were found between experimental groups so it was chosen as an endogenous reference gene to normalize qPCR data as it had a low inter-group variation and a similar level of expression to the analyzed genes. Statistical significance of relative gene expression between groups was analysed by one-way ANOVA using the software SigmaStat v.3.1 (SPSS Inc, Chicago, USA). Pearson correlations between the $\mathrm{qPCR}$ relative expression and microarray expression of both probes (average of individuals in each experimental group) were calculated for each gene. Statistical significance was established at $\mathrm{p}<0.05$.

\section{Additional material}

\section{Additional file 1: Complete lists of up or down-regulated genes in}

the microarray. The differentially expressed probes of the microarray are listed for each of the comparisons made ( $N$ vs. WS; $N$ vs. ST; N vs. STWS and ST Vs. STWS) for both day 3 and 7 of the experiment. For each comparison two tables are presented: one for the up-regulated probes and another for the down-regulated probes. A summary of the information available is also given in the first spreadsheet of the file.

Additional file 2: GOSLIM (Biological process) diagrams. The percentage of the GOSLIM categories is represented for all the transcripts in the microarray and also for the differentially expressed genes in the comparisons of day 3: N vs. WS; N vs. ST; N vs. STWS and ST vs. STWS.

Additional file 3: Top five Bio Functions identified for each comparison by IPA on day 3. Bio Functions for each category (Molecular and Cellular Functions, and Physiological System

Development and Function), the p-value and the number of implicated molecules are shown.

\section{Acknowledgements}

The authors acknowledge B. Louro and P. Pinto, for the help with the IPA software and $\mathrm{QPCR}$ technique, respectively. The work was funded by FINEFISH (COLL-012451) a European funded FP6 Project and Pluriannual funding to CCMAR from the Portuguese Science and Technology Foundation (FCT). FV was in receipt of a PhD fellowship from FCT (BD/ 17630/2004) and SG benefited from a mobility grant from AQUAGENOME (SSP8-044481) a European specific support action. MSC and MAST performed this work within the remit of the Adaptations and Physiology Workpackage of the Ecosystems Programme at the British Antarctic Survey.

\section{Author details}

${ }^{1}$ Comparative and Molecular Endocrinology Group, Centre for Marine Sciences (CCMAR), Universidade do Algarve, Campus de Gambelas, 8005-139 Faro, Portugal. ${ }^{2}$ Dipartimento di Sanità Pubblica, Patologia Comparata e Igiene Veterinaria, Università di Padova, 35020 Legnaro, Italy. ${ }^{3}$ British Antarctic Survey, Natural Environment Research Council, High Cross, Madingley Road, Cambridge, CB3 OET, UK.

\footnotetext{
Authors' contributions

FAV designed and conducted the sea bream experiment, performed microarray analysis and GPCR for microarray validation, analysed the results and wrote the manuscript; SG assisted in the sea bream experiment and the oligo-array hybridization; SF and MM conducted the oligo-array hybridization; MAST performed the microarray data analysis; RC carried out the histology; LB conducted the oligo-array hybridization and edited the manuscript; MSC assisted in the interpretation of results and writing of the manuscript; AVMC designed the experiment and edited the manuscript;
}

DMP designed and conducted the experiment, analysed the results and wrote the manuscript. All authors have read and approved the final manuscript.

Received: 24 December 2010 Accepted: 7 October 2011 Published: 7 October 2011

\section{References}

1. Quilhac A, Sire JY: Spreading, proliferation, and differentiation of the epidermis after wounding a cichlid fish, Hemichromis bimaculatus. Anat Rec 1999, 254:435-451.

2. Rotllant J, Redruello B, Guerreiro PM, Fernandes $H$, Canario AV, Power DM: Calcium mobilization from fish scales is mediated by parathyroid hormone related protein via the parathyroid hormone type 1 receptor. Regul Pept 2005, 132:33-40.

3. Simkiss K: Calcium metabolism of fish in relation to ageing. In Ageing of fish. Edited by: B. BT. Surrey: Gresham Press; 1973:1-12.

4. Sire JY, Huysseune A: Formation of dermal skeletal and dental tissues in fish: a comparative and evolutionary approach. Biol Rev Camb Philos Soc 2003, 78:219-249.

5. Whitear M: The skin of fishes including cyclostomes. Epidermis. Dermis. In Biology of the Integument 2 Vertebrates. Edited by: Bereiter-Hahn J, Matoltzy AG, Richards S. Heidelberg: Springer-Verlag; 1986:8-64.

6. Campinho MA, Silva N, Sweeney GE, Power DM: Molecular, cellular and histological changes in skin from a larval to an adult phenotype during bony fish metamorphosis. Cell Tissue Res 2007, 327:267-284.

7. Le Guellec D, Morvan-Dubois G, Sire JY: Skin development in bony fish with particular emphasis on collagen deposition in the dermis of the zebrafish (Danio rerio). Int J Dev Biol 2004, 48:217-231.

8. Ohira Y, Shimizu M, URA K, Takagi Y: Scale regeneration and calcification in goldfish Carassius auratus: quantitative and morphological processes. Fisheries Science 2007, 73:46-54.

9. Azuma K, Kobayashi M, Nakamura M, Suzuki N, Yashima S, Iwamuro S, Ikegame M, Yamamoto T, Hattori A: Two osteoclastic markers expressed in multinucleate osteoclasts of goldfish scales. Biochem Biophys Res Commun 2007, 362:594-600.

10. Pinto PI, Estevao MD, Redruello B, Socorro SM, Canario AV, Power DM: Immunohistochemical detection of estrogen receptors in fish scales. Gen Comp Endocrinol 2009, 160:19-29.

11. Suzuki N, Suzuki T, Kurokawa T: Suppression of osteoclastic activities by calcitonin in the scales of goldfish (freshwater teleost) and nibbler fish (seawater teleost). Peptides 2000, 21:115-124.

12. Yoshikubo H, Suzuki N, Takemura K, Hoso M, Yashima S, Iwamuro S, Takagi Y, Tabata MJ, Hattori A: Osteoblastic activity and estrogenic response in the regenerating scale of goldfish, a good model of osteogenesis. Life Sci 2005, 76:2699-2709.

13. Sire JY, Géraudie J: Fine structure of regenerating scales and their associated cells in the cichlid Hemichromis bimaculatus; (Gill). Cell and Tissue Research 1984, 237:537-547.

14. Iger $Y$, Abraham M: The process of skin healing in experimentally wounded carp. Journal of Fish Biology 1990, 36:421-437.

15. Bereiter-Hahn J, Zylberberg L: Regeneration of teleost fish scale. Comparative biochemistry and physiology 1993, 105A:625-641.

16. Sire JY, Allizard F, Babiar O, Bourguignon J, Quilhac A: Scale development in zebrafish (Danio rerio). J Anat 1997, 190(Pt 4):545-561.

17. Monnot MJ, Babin PJ, Poleo G, Andre M, Laforest L, Ballagny C, Akimenko MA: Epidermal expression of apolipoprotein $E$ gene during fin and scale development and fin regeneration in zebrafish. Developmental Dynamics 1999, 214:207-215.

18. Sire JY, Akimenko MA: Scale development in fish: a review, with description of sonic hedgehog (shh) expression in the zebrafish (Danio rerio). Int J Dev Biol 2004, 48:233-247.

19. Tingaud-Sequeira A, Forgue J, André M, Babin P: Epidermal transient down-regulation of retinol binding protein 4 and mirror expression of apolipoprotein $E b$ and estrogen receptor $2 a$ during zebrafish fin and scale development. Developmental Dynamics 2006, 235:3071-3079.

20. Kondo S, Kuwahara Y, Kondo M, Naruse K, Mitani H, Wakamatsu Y, Ozato K, Asakawa S, Shimizu N, Shima A: The medaka rs-3 locus required for scale development encodes ectodysplasin-A receptor. Curr Biol 2001, 11:1202-1206. 
21. De Vrieze E, Sharif F, Metz JR, Flik G, Richardson MK: Matrix metalloproteinases in osteoclasts of ontogenetic and regenerating zebrafish scales. Bone 2011, 48:704-712.

22. Fast MD, Sims DE, Burka JF, Mustafa A, Ross NW: Skin morphology and humoral non-specific defence parameters of mucus and plasma in rainbow trout, coho and Atlantic salmon. Comp Biochem Physiol A Mol Integr Physiol 2002, 132:645-657.

23. Mittal AK, Munshi JS: On the regeneration and repair of superficial wounds in the skin of Rita rita (Ham.) (Bagridae, Pisces). Acta Anat (Basel) 1974, 88:424-442.

24. Mugiya $Y$ : The source of calcium in the regenerating scales of the goldfish, Carassius auratus. Comparative Biochemistry Phisiology 1980, 66A:521-524.

25. Persson $P$, Takagi $Y$, Björnsson BT: Tartrate resistant acid phosphatase as a marker for scale resorption in rainbow trout, Oncorhynchus mykiss: effects of estradiol-17 $\beta$ treatment and refeeding. Fish Physiology and Biochemistry 1995, 14:329-339.

26. Flik G, Fenwick JC, Kolar Z, Mayer-Gostan N, Wendelar Bonga SE: Effects of ovine prolactin on calcium uptake and distribution in Oreochromis mossambicus. Am J Physiol 1986, 250:R161-166.

27. Flik G, Schoenmakers TJ, Groot JA, van Os CH, Wendelaar Bonga SE: Calcium absorption by fish intestine: the involvement of ATP- and sodium-dependent calcium extrusion mechanisms. J Membr Biol 1990 113:13-22.

28. Hunn JB: Role of calcium in gill function in freshwater fishes. Comparative Biochemistry and Physiology Part A: Physiology 1985, 82:543-547.

29. White KE, Larsson TE, Econs MJ: The roles of specific genes implicated as circulating factors involved in normal and disordered phosphate homeostasis: frizzled related protein-4, matrix extracellular phosphoglycoprotein, and fibroblast growth factor 23. Endocr Rev 2006, 27:221-241.

30. Quilhac A, Sire JY: Restoration of the subepidermal tissues and scale regeneration after wounding a cichlid fish, Hemichromis bimaculatus. Journal of Experimental Zoology 1998, 281:305-327.

31. Polakof S, Arjona F, Sangiao-Alvarellos S, Martín del Río M, Mancera J, Soengas J: Food deprivation alters osmoregulatory and metabolic responses to salinity acclimation in gilthead sea bream Sparus auratus. Journal of Comparative Physiology B: Biochemical, Systemic, and Environmental Physiology 2006, 176:441-452.

32. Sangiao-Alvarellos S, Arjona FJ, del Rio MPM, Miguez JM, Mancera JM, Soengas JL: Time course of osmoregulatory and metabolic changes during osmotic acclimation in Sparus auratus. J Exp Biol 2005, 208:4291-4304.

33. Sangiao-Alvarellos S, Laiz-Carrion R, Guzman JM, Martin del Rio MP, Miguez JM, Mancera JM, Soengas JL: Acclimation of $S$. aurata to various salinities alters energy metabolism of osmoregulatory and nonosmoregulatory organs. Am J Physiol Regul Integr Comp Physiol 2003, 285:R897-907.

34. Guerreiro PM, Fuentes J, Canario AV, Power DM: Calcium balance in sea bream (Sparus aurata): the effect of oestradiol-17beta. J Endocrinol 2002, 173:377-385.

35. Guerreiro PM, Renfro JL, Power DM, Canario AVM: The parathyroid hormone family of peptides: structure, tissue distribution, regulation, and potential functional roles in calcium and phosphate balance in fish. Am J Physiol Regul Integr Comp Physiol 2007, 292:R679-696.

36. Ferraresso S, Vitulo N, Mininni AN, Romualdi C, Cardazzo B, Negrisolo E, Reinhardt R, Canario AV, Patarnello T, Bargelloni L: Development and validation of a gene expression oligo microarray for the gilthead sea bream (Sparus aurata). BMC Genomics 2008, 9:580

37. Uniprot Database. [http://www.uniprot.org].

38. O'Farrell C, Vaghefi N, Cantonnet M, Buteau B, Boudinot P, Benmansour A: Survey of transcript expression in rainbow trout leukocytes reveals a major contribution of interferon-responsive genes in the early response to a rhabdovirus infection. J Virol 2002, 76:8040-8049.

39. Zhang YB, Gui HF: Identification and expression analysis of two IFNinducible genes in crucian carp (Carassius auratus L.). Gene 2004, 325:43-51.

40. Rutkowski MJ, Sughrue ME, Kane AJ, Ahn BJ, Fang S, Parsa AT: The complement cascade as a mediator of tissue growth and regeneration. Inflamm Res 2010.
41. Jones SR: The occurrence and mechanisms of innate immunity against parasites in fish. Dev Comp Immunol 2001, 25:841-852

42. Sitja-Bobadilla A: Fish immune response to Myxozoan parasites. Parasite 2008, 15:420-425.

43. Whyte SK: The innate immune response of finfish-a review of current knowledge. Fish Shellfish Immunol 2007, 23:1127-1151.

44. Bukovsky A, Caudle MR, Carson RJ, Gaytan F, Huleihel M, Kruse A, Schatten $\mathrm{H}$, Telleria CM: Immune physiology in tissue regeneration and aging, tumor growth, and regenerative medicine. Aging (Albany NY) 2009, 1:157-181.

45. Shiraki N, Harada S, Ogaki S, Kume K, Kume S: Identification of DAF1/CD55, a novel definitive endoderm marker. Cell Struct Funct 2010, 35:73-80.

46. Gorczynski RM, Chen Z, Shivagnahnam S, Taseva A, Wong K, Yu K, Khatri I: Potent Immunosuppression by a Bivalent Molecule Binding to CD200R and TGF-[beta]R. Transplantation 2010, 90:150-159.

47. Jiang S, Zhao L, Purandare B, Hantash BM: Differential expression of stem cell markers in human follicular bulge and interfollicular epidermal compartments. Histochem Cell Biol 2010, 133:455-465.

48. Kobayashi T, Iwasaki T, Amagai M, Ohyama M: Canine follicle stem cell candidates reside in the bulge and share characteristic features with human bulge cells. J Invest Dermatol 2010, 130:1988-1995.

49. Lee SW, Reimer CL, Fang L, Iruela-Arispe ML, Aaronson SA: Overexpression of kinase-associated phosphatase (KAP) in breast and prostate cancer and inhibition of the transformed phenotype by antisense KAP expression. Mol Cell Biol 2000, 20:1723-1732.

50. von der Lehr N, Johansson S, Wu SQ, Bahram F, Castell A, Cetinkaya C, Hydbring P, Weidung I, Nakayama K, Nakayama Kl, et al: The F-Box protein Skp2 participates in c-Myc protelosornal degradation and acts as a cofactor for c-Myc-regulated transcription. Mol Cell 2003, 11:1189-1200.

51. Li WQ, Lan ZD, Wu HY, Wu SC, Meadows J, Chen J, Zhu V, Dai W: BUBR1 phosphorylation is regulated during mitotic checkpoint activation. Cell Growth Differ 1999, 10:769-775.

52. Pinto $P$, Matsumura $H$, Thorne M, Power $D$, Terauchi $R$, Reinhardt $R$, Canario A: Gill transcriptome response to changes in environmental calcium in the green spotted puffer fish. BMC Genomics 2010, 11:476.

53. Mungrue IN, Pagnon J, Kohannim O, Gargalovic PS, Lusis AJ: CHAC1/ MGC4504 is a novel proapoptotic component of the unfolded protein response, downstream of the ATF4-ATF3-CHOP cascade. J Immunol 2009, 182:466-476.

54. Deweindt C, Albagli O, Bernardin F, Dhordain P, Quief S, Lantoine D, Kerckaert JP, Leprince D: The Laz3/Bcl6 Oncogene Encodes a SequenceSpecific Transcriptional Inhibitor - a Novel Function for the Btb/Poz Domain as an Autonomous Repressing Domain. Cell Growth Differ 1995, 6:1495-1503

55. Ito $Y$, Oike $Y$, Yasunaga K, Hamada K, Miyata K, Matsumoto S, Sugano S, Tanihara H, Masuho $Y$, Suda T: Inhibition of angiogenesis and vascular leakiness by angiopoietin-related protein 4. Cancer Res 2003, 63:6651-6657.

56. LeBoeuf RD, Ban EMH, Green MM, Stone AS, Propst SM, Blalock JE, Tauber JD: Molecular cloning, sequence analysis, expression, and tissue distribution of suppressin, a novel suppressor of cell cycle entry. J Biol Chem 1998, 273:361-368.

57. Popov N, Herold S, Llamazares M, Schulein C, Eilers M: Fbw7 and Usp28 regulate myc protein stability in response to DNA damage. Cell Cycle 2007, 6:2327-2331.

58. Navarro I, Gutiérrez J: Fasting and Starvation. In Metabolic biochemistry, biochemistry and molecular biology of fishes. Volume 4. Edited by: Hochachka PW MT. Amsterdam: Elsevier; 1995:393-434

59. Sangiao-Alvarellos S, Guzman JM, Laiz-Carrion R, Miguez JM, Martin Del Rio MP, Mancera JM, Soengas JL: Interactive effects of high stocking density and food deprivation on carbohydrate metabolism in several tissues of gilthead sea bream Sparus auratus. J Exp Zool A Comp Exp Biol 2005, 303:761-775.

60. Sheridan MA, Mommsen TP: Effects of nutritional state on in vivo lipid and carbohydrate metabolism of coho salmon, Oncorhynchus kisutch. Gen Comp Endocrinol 1991, 81:473-483.

61. Morisada T, Kubota Y, Urano T, Suda T, Oike Y: Angiopoietins and Angiopoietin-Like Proteins in Angiogenesis. Endothelium: Journal of Endothelial Cell Research 2006, 13:71-79. 
62. Yoshida K, Shimizugawa T, Ono M, Furukawa H: Angiopoietin-like protein 4 is a potent hyperlipidemia-inducing factor in mice and inhibitor of lipoprotein lipase. J Lipid Res 2002, 43:1770-1772.

63. Hosokawa N, Hara T, Kaizuka T, Kishi C, Takamura A, Miura Y, lemura S, Natsume T, Takehana K, Yamada N, et al: Nutrient-dependent mTORC1 Association with the ULK1-Atg13-FIP200 Complex Required for Autophagy. Mol Biol Cell 2009, 20:1981-1991.

64. Zimmermann R, Strauss JG, Haemmerle G, Schoiswohl G, BirnerGruenberger R, Riederer M, Lass A, Neuberger G, Eisenhaber F, Hermetter A, Zechner R: Fat Mobilization in Adipose Tissue Is Promoted by Adipose Triglyceride Lipase. Science 2004, 306:1383-1386.

65. Sarparanta J: Biology of myospryn: what's known? J Muscle Res Cell Motil 2008, 29:177-180.

66. Whittock NV, McLean WHI: Genomic organization, amplification, fine mapping, and intragenic polymorphisms of the human hemidesmosomal tetraspanin CD151 gene. Biochem Biophys Res Commun 2001, 281:425-430.

67. Lecker SH, Jagoe RT, Gilbert A, Gomes M, Baracos V, Bailey J, Price SR, Mitch WE, Goldberg AL: Multiple types of skeletal muscle atrophy involve a common program of changes in gene expression. Faseb J 2004, 18:39-51.

68. Mommsen TP: Salmon spawning migration and muscle protein metabolism: the August Krogh principle at work. Comp Biochem Physiol B-Biochem Mol Biol 2004, 139:383-400

69. Houston Al, McNamara JM, Barta Z, Klasing KC: The effect of energy reserves and food availability on optimal immune defence. Proc $R$ Soc $B$ Biol Sci 2007, 274:2835-2842.

70. Martin S, Douglas A, Houlihan D, Secombes C: Starvation alters the liver transcriptome of the innate immune response in Atlantic salmon (Salmo salar). BMC Genomics 2010, 11:418.

71. Chapman E, Best MD, Hanson SR, Wong CH: Sulfotransferases: structure, mechanism, biological activity, inhibition, and synthetic utility. Angew Chem Int Ed Engl 2004, 43:3526-3548.

72. Kirchner S, McDaniel NK, Sugiura SH, Soteropoulos P, Tian B, Fletcher JW, Ferraris RP: Salmonid microarrays identify intestinal genes that reliably monitor P deficiency in rainbow trout aquaculture. Anim Genet 2007, 38:319-331.

73. Hershko A, Ciechanover A: The ubiquitin system. Annu Rev Biochem 1998, 67:425-479.

74. Braverman N, Lin P, Moebius FF, Obie C, Moser A, Glossmann H, Wilcox WR, Rimoin DL, Smith $M$, Kratz $L$, et al: Mutations in the gene encoding 3 beta-hydroxysteroid-Delta(8),Delta(7)-isomerase cause X-linked dominant Conradi-Hunermann syndrome. Nature Genet 1999, 22:291-294.

75. Guerreiro PM, Fuentes J, Power DM, Ingleton PM, Flik G, Canario AV: Parathyroid hormone-related protein: a calcium regulatory factor in sea bream (Sparus aurata L.) larvae. Am J Physiol Regul Integr Comp Physiol 2001, 281:R855-860.

76. Dola M, Utpal S, Bhattacharyya SP, Dilip M: Inhibition of whole body $\mathrm{Ca}^{2+}$ uptake in fresh water teleosts, Channa punctatus and Cyprinus carpio in response to salmon calcitonin. Journal of Experimental Zoology Part A: Comparative Experimental Biology 2004, 301A:882-890.

77. Mukherjee D, Sen U, Bhattacharyya SP, Mukherjee D: The effects of calcitonin on plasma calcium levels and bone metabolism in the fresh water teleost Channa punctatus. Comparative Biochemistry and Physiology - Part A: Molecular \& Integrative Physiology 2004, 138:417-426.

78. Still $H$, Vince $P$, Cowell JK: The Third Member of the Transforming Acidic Coiled Coil-Containing Gene Family, TACC3, Maps in 4p16, Close to Translocation Breakpoints in Multiple Myeloma, and Is Upregulated in Various Cancer Cell Lines. Genomics 1999, 58:165-170.

79. Yim EK, Tong SY, Ho EM, Bae JH, Um SJ, Park JS: Anticancer effects on TACC3 by treatment of paclitaxel in HPV-18 positive cervical carcinoma cells. Oncol Rep 2009, 21:549-557.

80. Ueno M, Itoh M, Sugihara K, Asano M, Takakura N: Both alleles of PSF1 are required for maintenance of pool size of immature hematopoietic cells and acute bone marrow regeneration. Blood 2009, 113:555-562.

81. Bitoun M, Maugenre S, Jeannet PY, Lacene E, Ferrer X, Laforet P, Martin JJ, Laporte J, Lochmuller $\mathrm{H}$, Beggs $\mathrm{AH}$, et al: Mutations in dynamin 2 cause dominant centronuclear myopathy. Nature Genet 2005, 37:1207-1209.

82. Wang HY, Parry S, Macones G, Sammel MD, Kuivaniemi H, Tromp G, Argyropoulos G, Halder I, Shriver MD, Romero R, Strauss JF: A functional SNP in the promoter of the SERPINH1 gene increases risk of preterm premature rupture of membranes in African Americans. Proc Natl Acad Sci USA 2006, 103:13463-13467.

83. Witten PE, Hall BK: Seasonal changes in the lower jaw skeleton in male Atlantic salmon (Salmo salar L.): remodelling and regression of the kype after spawning. J Anat 2003, 203:435-450.

84. R Development Core Team: R: a language and environment for statistical computing. In $R$ : a language and environment for statistical computing Edited by: R Foundation for Statistical Computing 2005.

85. Smyth G, Michaud J, Scott H: Use of within-array replicate spots for assessing differential expression in microarray experiments. Bioinformatics 2005, 21:2067-2075.

86. Smyth GK: Linear models and empirical bayes methods for assessing differential expression in microarray experiments. Stat Appl Genet Mol Biol 2004, 3, Article3.

87. Benjamini Y, Hochberg Y: Controlling the False Discovery Rate - a Practical and Powerful Approach to Multiple Testing. J R Stat Soc Ser BMethodol 1995, 57:289-300.

88. Edgar R, Domrachev M, Lash AE: Gene Expression Omnibus: NCBI gene expression and hybridization array data repository. Nucleic Acids Res 2002, 30:207-210.

89. Ashburner M, Ball CA, Blake JA, Botstein D, Butler H, Cherry JM, Davis AP, Dolinski K, Dwight SS, Eppig JT, et al: Gene Ontology: tool for the unification of biology. Nature Genet 2000, 25:25-29.

\section{doi:10.1186/1471-2164-12-490}

Cite this article as: Vieira et al:: Skin healing and scale regeneration in fed and unfed sea bream, Sparus auratus. BMC Genomics 2011 12:490.

\section{Submit your next manuscript to BioMed Central and take full advantage of:}

- Convenient online submission

- Thorough peer review

- No space constraints or color figure charges

- Immediate publication on acceptance

- Inclusion in PubMed, CAS, Scopus and Google Scholar

- Research which is freely available for redistribution 